\title{
SKLO Z ODPADNÍCH JÍMEK NA DRŮBEŽÍM TRHU V OPAVĚ A POZŮSTATKY SKLENÁŘSKÉ DÍLNY
}

\author{
KATEŘINA VAĎUROVÁ
}

\begin{abstract}
Abstrakt: Příspěvek je zaměren na vyhodnocení souborů skla z odpadnich jímek na Drůbežim trhu v Opavě, ze kterých byla získána torza více než 170 skleněných nádob a početné fragmenty okenního skla. Přestože archeologické nálezy dokládaji, že již ve 13. století méli zdejši obyvatelé přistup ke kvalitnímu stolnímu sklu, pochází většina materiálu až z období pozdniho středověku a raného novověku (15. až 16. století). Výjimečný nález rozšiřujicí naše znalosti o opavských řemeslnícich ve středověku představuji stovky fragmentů okennich skel, které lze interpretovat jako výrobni odpad po sekundárním zpracování okenních tabuli, a tedy doklad působeni sklenáre v této lokalitě v prvni polovině 15. století.
\end{abstract}

Kličová slova: středověk-raný novověk - sklo-okenni sklo-sklenář.

\section{Glass from refuse pits in the Poultry Market, Opava and the remains of a glass workshop}

\begin{abstract}
This contribution centres on the assessment of a glass series from refuse pits in the Poultry Market, Opava which yielded the fragments of over 170 glass vessels, as well as numerous fragments of window glass. Despite the fact that archaeological finds confirm that the local inhabitants had access to high-quality table glass as early as the 13th century, the majority of finds come from the late Middle Ages and from the early modern age (15th and 16th century). The exceptional find of hundreds of fragments of window glass expands our knowledge of Opava craftsmen in the Middle Ages. The fragments can be interpreted as production waste after the secondary processing of window panes, and thus bear witness of the activity of a glazier on this site in the first half of the 15th century.
\end{abstract}

Key words: Middle Ages - early modern age - glass - window glass - glazier.

\section{Úvod. Lokalizace výzkumu}

Z archeologických výzkumů historického centra Opavy pocházejí početné nálezy středověkého (například Břečková 2017; Sedláčková 2004a) a raně novověkého skla (Pavelčík-Štěrbová 1997; Teryngerová 1997). Jeden z nejrozsáhlejších souborů byl získán ze série odpadních jímek zachycených ve vnitrobloku vymezeném Dolním náměstím, ulicí Masařskou, Mezi Trhy a Masarykovou tř́idou. Již v letech 2005 až 2007 zde byl pod vedením NPÚ, ÚOP Ostrava, proveden předstihový archeologický výzkum v souvislosti s rekonstrukcí vnitrobloku na Drůbežím trhu. Na něj poté navázal archeologický dohled a výzkum realizovaný již v průběhu stavebních prací (č. akce 50/05). Při předstihové fázi výzkumu byla prozkoumána plocha ležící v zadních částech původních stř̌edověkých parcel, kde se podle stabilního katastru až do druhé světové války nacházely domy čp. 317-321 tvořící východní linii ulice Mezi Trhy, na nárožní parcele domu čp. 324 a sousedním městišti s domy čp. 325 a 326.

Velkou část nemovitostí na Dolním náměstí a v ulici Mezi Trhy představovaly plnoprávné domy s právem čtyř várek piva ročně a s právem vinného nálevu (domy čp. 324 a 325; Bakala 1974, 13-18), zatímco v severovýchodní části ulice Mezi Trhy se nacházely spíše domy třívárečné (čp. 318-320, 326), méně čtyřvárečné (čp. 321, 323; Fitz b. d.). Přestože některé tyto domy nedisponovaly plným rejstříkem práv, patřily díky své poloze v exponované části města k prestižním nemovitostem. Parcelace zdejších městišt' prošla ve středověku a novověku různými proměnami, které pokračovaly až do 19 . století. Při poválečné obnově ve druhé polovině 20 . století pak byla původní historická zástavba nahrazena několika panelovými domy s volným prostranstvím (Kiecoň-Zezula 2007, 7).

Při výzkumu byla zachycena řada archeologických situací souvisejících s hospodářským zázemím středověkých domů. Během 13. až 14. století došlo v lokalitě k výraznému nárůstu terénu, jak dokládají místy až 3,5 m mocná souvrství tvořená převážně přemístěným podložím, 
komunikačními horizonty a humusovitými uloženinami (Kolář-Zezula 2014, 551-553). Bohatý materiál byl získán ze série odpadních jímek využívaných $\mathrm{v}$ závěru středověku, $\mathrm{v}$ některých prŕípadech až do počátku raného novověku (obr. 1). V zadních částech parcel domů č. 319 a 320 byly zachyceny odpadní jímky 500, 504, 505, 508, 510 a 515 . V prostoru mezi jímkami 504 a 510 se podařilo zdokumentovat reprezentativní souvrství od počátku městského osídlení až po novověk. Další jímky respektovaly hranici parcel u domu čp. 324 a městišt' v ulici Mezi Trhy. $\mathrm{K}$ domu č. 325 pak náležely dvě jímky, a to 568 a 570 . Zdokumentovány však byly i novověké nálezové situace, např́íklad vápenná

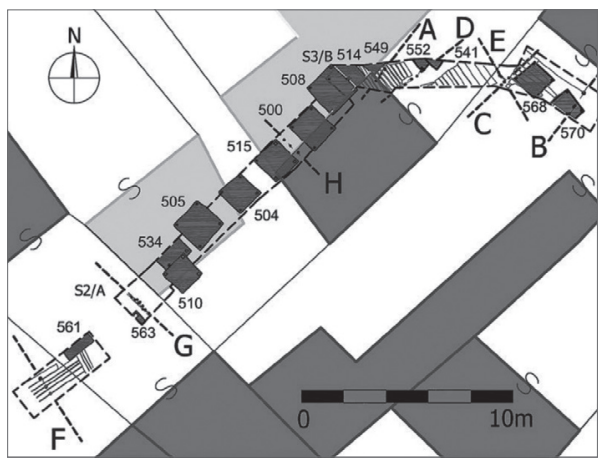

Obr. 1. Lokalizace odpadních jímek na indikační skice stabilního katastru z roku 1836. Podle Kolář-Zezula 2014, Abb. 4.

Abb. 1. Lokalisierung der Abfallgruben in der Indikationsskizze des stabilen Katasters aus dem Jahr 1836. Nach Kolář-Zezula 2014, Abb. 4. jáma, nevýrazné souvrství a suterén domu čp. 325 na Dolním náměstí (viz Kiecoň-Zezula 2007, 10-21; 2007a). Kromě dřevěných výrobků, množství běžné kuchyňské keramiky a džbánů a pohárů, které lze spojit s výčepem piva v těchto právovárečných domech, byly z odpadních jímek získány i výrobky svědčící o vysoké úrovni životního stylu jejich majitelů (např́iklad Břečková a kol. 2018, 211, obr. na s. 210 a 212). Do této kategorie patří také početné nálezy skleněných nádob.

\section{Popis skel a jejich nálezového kontextu}

Skleněné předměty byly získány z několika odpadních jímek a kulturních vrstev zachycených v sondách S2 až S5. Soubory skla z jednotlivých jímek se však výrazně kvantitativně lišily. Zatímco některé jímky neobsahovaly žádné skleněné fragmenty či jen jednotlivé zlomky, z jiných byly získány desítky nádob a četné fragmenty okenního skla (graf 1). Vedle typologicko-chronologického vyhodnocení získaných nálezů skel byla pozornost věnována i jejich prvkovému složení, k jehož zjištění byly použity metody SEM/EDS (skenovací elektronová mikroskopie s EDS analyzátorem) a XRF (rentgenová fluorescenční spektrofotometrie). ${ }^{1}$ Za provedení a vyhodnocení všech analýz děkuji doc. Dr. Ing. Daně Rohanové z Vysoké školy chemicko-technologické v Praze.

V sondě S2, podobně jako i v sondě S3, se již od počátku výzkumu jevily jako výrazný prvek odpadní jímky často porušující starší situace. Na úrovni vrstvy 117 byla zdokumentována ústí tří odpadních jímek 504, 505 a 510, jejichž výplň tvořily humózní a rašeliništní vrstvy s materiálem z 15. až 16. století. V jihozápadním rohu sondy bylo zachyceno ústí jímky 534, která však nebyla kompletně prozkoumána a byla navíc narušena mladší jímkou 510 . V sondě S3 byla již po skrytí několika desítek centimetrů recentních vrstev zachycena ústí odpadních jímek 500, 508 a 515, jež byla v superpozici se starší jímkou 514 (Kiecoň-Zezula 2007, 12-13). Ve všech těchto jímkách byly nalezeny četné skleněné fragmenty a torza několika desítek nádob. Nejpočetnější kolekce skla čítající minimálně 41-46 nádob pochází z jímky 508 zaplňované v průběhu 15 . a 16. století. V sondě S4 byly zdokumentovány odpadní jímky 561 a 564, které ale nemohly být v úplnosti zkoumány z důvodu zásahu do profilů sondy. Nejstarší doloženou situací je objekt 559 zahloubený do podloží a interpretovaný jako suterén nadzemní dřevohliněné stavby. V těchto objektech však, až na jediný zlomek z jímky 561, nebylo sklo zachyceno. Na rozdíl od sond S2 až S4 nebyl prostor sondy S5 výrazně porušen zahloubenými objekty, díky čemuž bylo možné získat podrobnější

1 Analýzy SEM/EDS byly provedeny na elektronovém mikroskopu Jeol JSM 6510 vybaveném EDS detektorem SSD Inca v režimu zpětně odražených sekundárních elektronů. Vzorky pro XRF byly analyzovány pomocí XRF spektrometru ARL 9400 XP v Centrálních laboratořích VŠCHT (oddělení RTG analýzy; viz Vad’urová 2021, 25). 


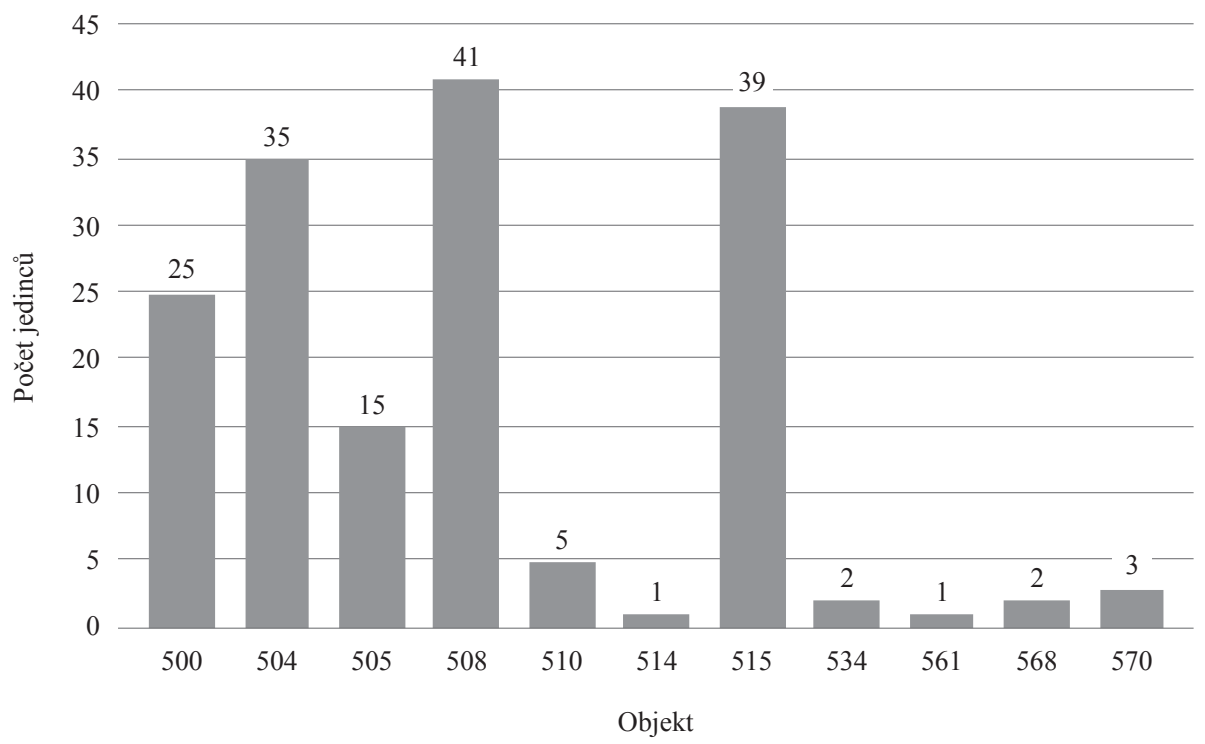

Graf 1. Minimální počty nádob v jednotlivých odpadních jímkách.

Diagramm 1. Mindestanzahl an Gefäßen in den einzelnen Abwassergruben.

informace o dění na dotčených parcelách (Kiecoň-Zezula 2007, 15-17). Výjimkou jsou dvě odpadní jímky 568 a 570, která ale také nebyla prozkoumána celá. Skleněné fragmenty tvoří pouze minoritní složku výplně těchto objektů.

\section{Objekt 500}

Popis: odpadní jímka čtvercového půdorysu s vnitřní dřevěnou konstrukcí

Výplň: Vrstvy humózních až rašeliništních hlín s obsahem makrozbytků (s. j. 162, 161, 141, 134) ve svrchní části přehrazené dřevěnou deskou a dosypané vrstvami 142, 140, 139, 137, 136, 131 a 130. Jímku uzavírala vrstva přemístěného podloží s. j. 107 s obsahem kamenů, která sloužila jako ucpávka proti zápachu. Vedle běžné keramiky bylo v jímce nalezeno polévané aquamanile, mosazná miska a náhrdelník z jantarových korálků.

Datace: 15.-16. století

Literatura: Břečková a kol. 2018, 210-212, 224; Kiecoň-Zezula 2007, 13

Popis skel: Z odpadní jímky 500 byl získán bohatý soubor skla z 15 . až 16. století. U jejího dna se nacházely vrstvy 161 a 162 bez skleněných předmětů. Nejméně 24 až 28 skleněných nádob a několik okenních terčíků s přehnutým (obr. 3:21) i jednoduchým zataveným okrajem pochází až z vrstvy 141, která zabírala většinu výplně jímky.

V souboru z této uloženiny jsou zastoupeny především láhve různých tvarů, velikostí i dekoru. Mezi pozdně gotické tvary patří číše s výrazně štíhlou nožkou a terčovitou patkou (obr. 3:2) a dvě číše nebo číšky s hutnickým dekorem. První z nich zdobí klikatky z hladkého 


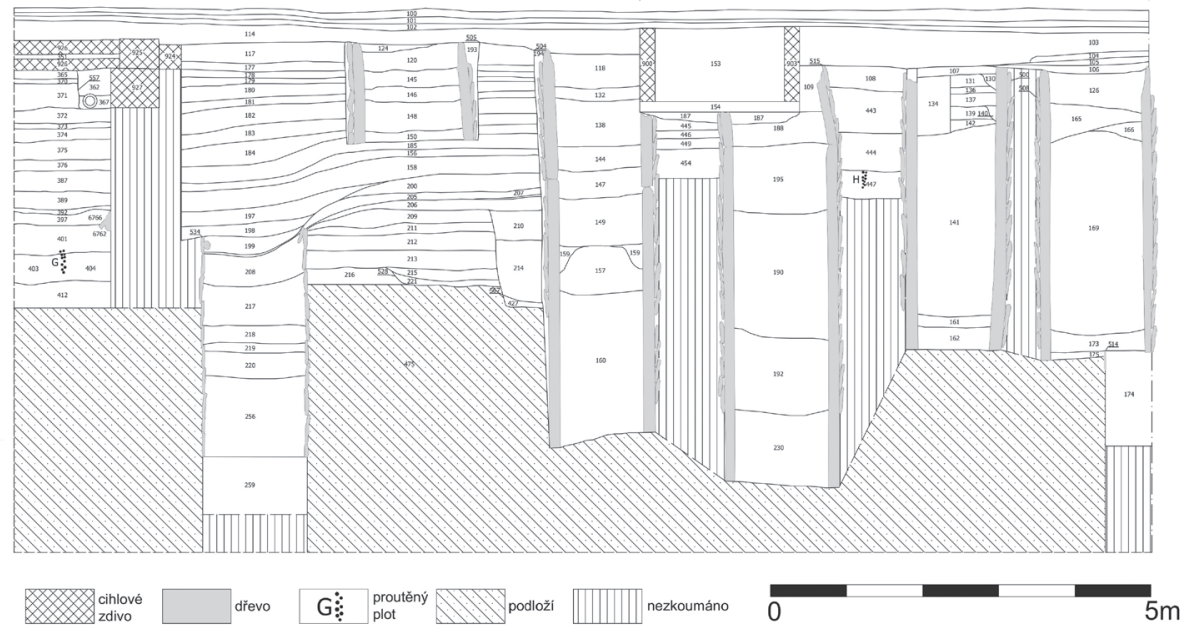

Obr. 2. Stratigrafická situace odpadních jímek 500, 504, 505, 508, 515 a 534. Podle Kiecoň-Zezula 2007 , plán 006.

Abb. 2. Stratigraphische Situation der Abwassergruben 500, 504, 505, 508, 515 und 534. Nach Kiecoň-Zezula 2007, Planskizze 006 .

vlákna a horizontální vlákno promačkávané rádélkem (obr. 3:3), zatímco na druhé je motiv vláken promačkávaných rádélkem doplněn výrazně vytaženými nálepy. Je možné, že tyto zlomky spolu s miskovitým ústím pocházejí z krautstrunku nebo stangenglasu. Jako krautstrunk je označována nádoba s nízkým miskovitým ústím a soudkovitým tělem zdobeným velkými nálepy, které bývají v horní části zaštípnuté (Baumgartner-Krueger 1988, 336-361). Další nápojové sklo představuje drobná číška zdobená pod okrajem modrými vlákny (obr. 3:5), číška s optickým dekorem svislých žeber (obr. 3:6) a číška se dnem spirálovitě ovinutým hladkým vláknem (obr. 3:4). Číška s modrými vlákny v okraji byla vyrobena z draselno-vápenatého skla renesančního složení, které se podobá výrobkům regionálních skláren (tab. 3:A22). Mezi čistě renesanční tvary již patří tř́i poháry, z nichž jeden nese optický dekor (obr. 3:7-9; tab. 3:A25), a tři číše na duté zvonovité patce (obr. 3:1; tab. 3:A23).

Do sortimentu stolního skla patř́ láhev s hruškovitým tělem (obr. 3:17) a čtyři láhve s kulovitým tělem a vyšším štíhlým hrdlem vyrobené z nazelenalého skla (obr. 3:12-13, 16), z nichž tři jsou nezdobené, zatímco čtvrtá je zdobena šikmými žebry vzniklými vyfouknutím baňky skla do formy. Optickým dekorem, a to v podobě rout a žeber, byly zdobeny i další dvě láhve, jejichž sklo bylo zkorodované (obr. 3:14). U jedné láhve z nazelenalého skla a zkorodované láhve se žebry byly provedeny analýzy prvkového složení, které ukázaly jejich rozdílné složení. Zatímco první exemplář byl již vyroben ze skla renesančního složení (tab. 3:A21), zkorodovaná láhev ještě patří mezi pozdně gotické zboží (tab. 2:A6). Vzácným nálezem je torzo džbánku nebo konvičky s optickým dekorem a s ústím ovinutým modrým vláknem (obr. 3:11) a poutnická láhev se dvěma drobnými oušky (obr. 3:10). Oba tyto tvary se v archeologickém materiálu objevují častěji až od druhé poloviny 16. století, zatímco nálezy z Drůbežího trhu lze na základě charakteru koroze řadit nejpozději do první poloviny 16. století. Také sklo láhve s čočkovitým tělem bylo silně zkorodované (obr. 3:19). Z nádoby blíže neurčitelného tvaru pochází zlomek páskového ucha (obr. 3:18). Vedle běžně dostupného nazelenalého skla měli opavští měštané v 16. století přístup i k nádobám z barvených skel, jak dokládají zlomky tmavě modrého skla (tab. 3:A24). Kolekci uzavírají dvě nádoby opatřené v horní části otvorem a výlevkou, označované jako „mucholapky“ (obr. 3:20) a zlomky čtyř den, která nelze s jistotou přiřadit ke konkrétním nádobám (obr. 3:15). 


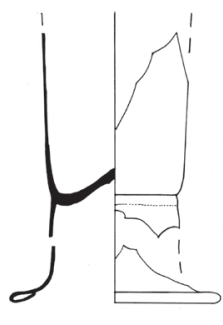

1 (A23)
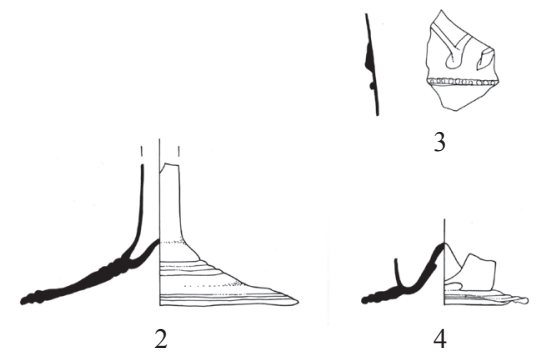

4
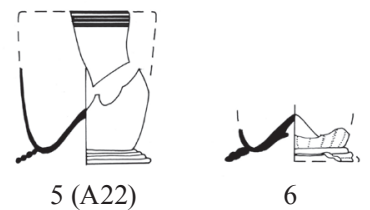

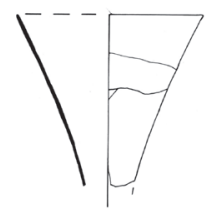

7

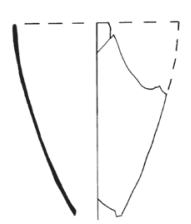

8

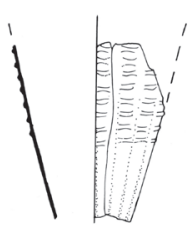

9 (A25)

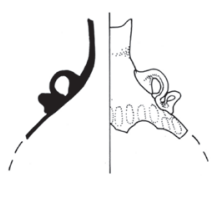

10

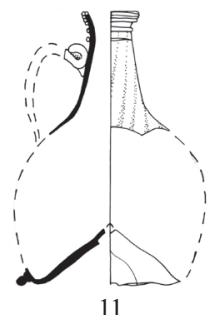

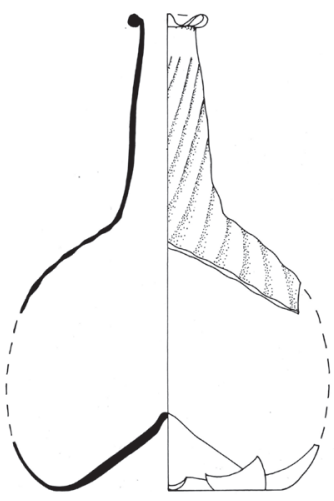

12
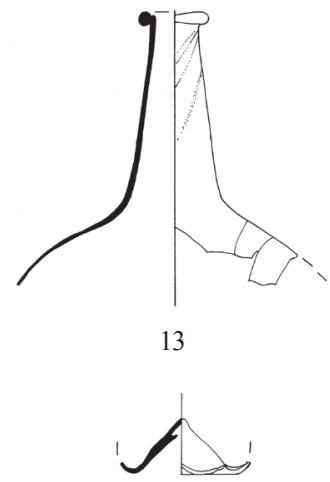

15

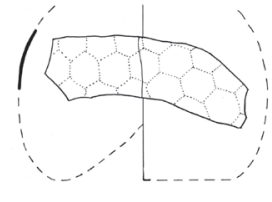

14

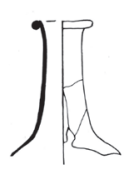

16

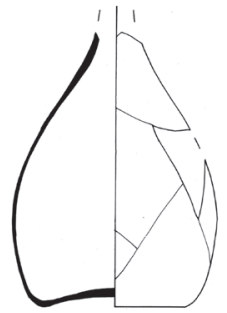

17
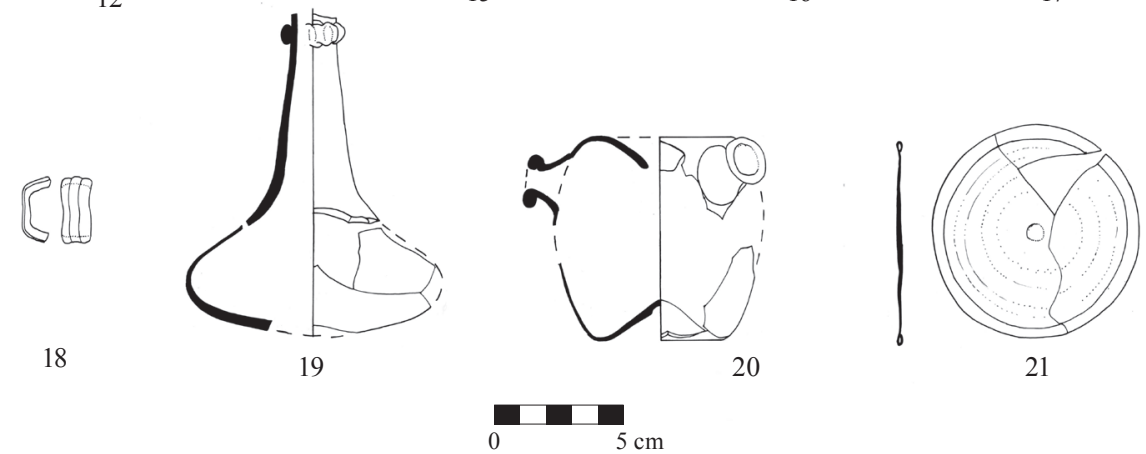

Obr. 3. Skleněné nálezy z jímky 500.

Abb. 3. Glasfunde aus Grube 500. 


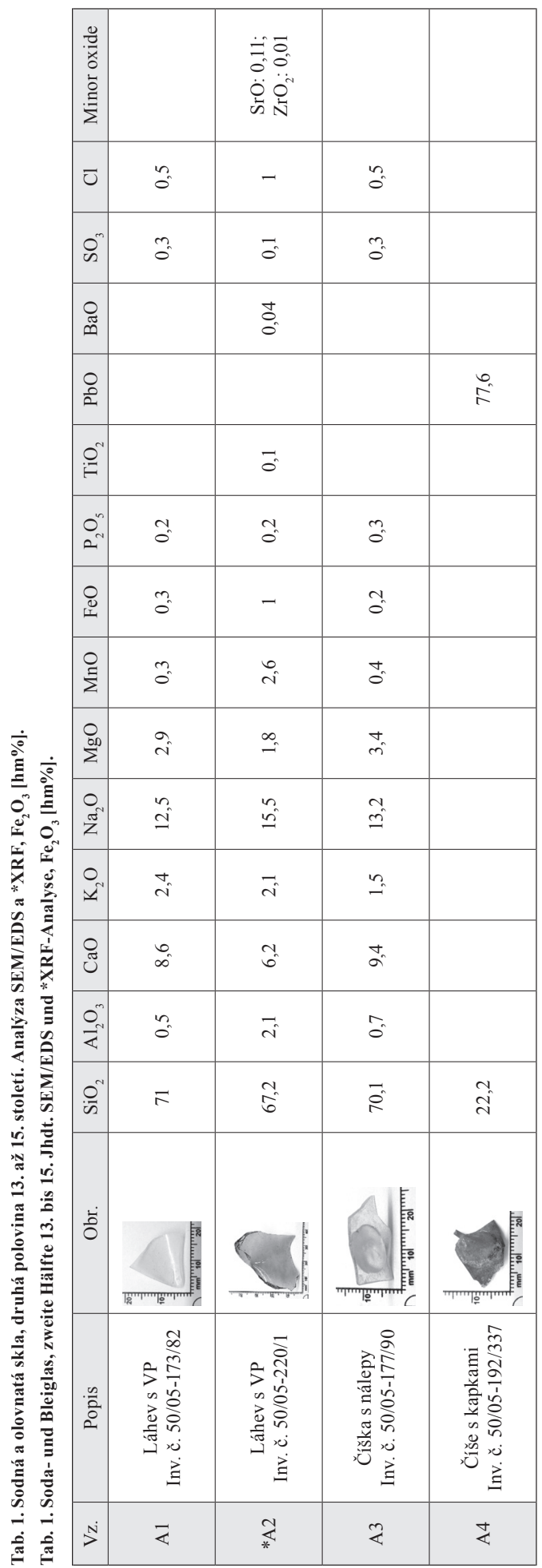

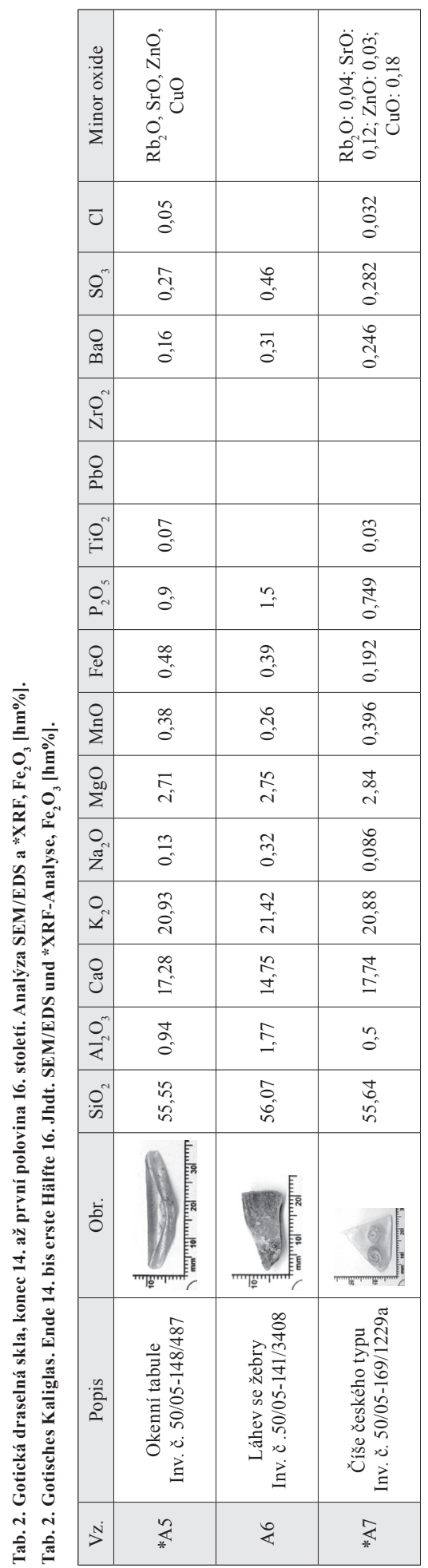




\begin{tabular}{|c|c|c|c|c|c|c|c|c|c|c|}
\hline & 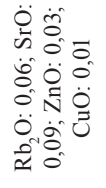 & 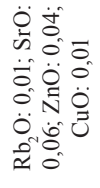 & & & 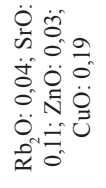 & 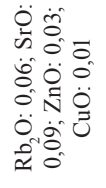 & 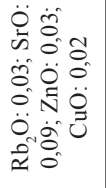 & & & \\
\hline & ô. & \begin{tabular}{l}
+ \\
\multirow{2}{*}{} \\
0 \\
0
\end{tabular} & & & & $\begin{array}{l}\hat{0} \\
\hat{0} \\
0\end{array}$ & $\begin{array}{l}\text { ते } \\
\text { ठ̊. } \\
\text { ठ }\end{array}$ & & & \\
\hline & $\begin{array}{l}\infty \\
\stackrel{0}{0} \\
i \\
0\end{array}$ & $\begin{array}{l}\text { ڤे } \\
\text { 亏ે }\end{array}$ & ले & के & & \begin{tabular}{l}
0 \\
\multirow{2}{*}{} \\
ה.
\end{tabular} & 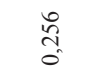 & $\overrightarrow{0}_{0}$ & $\begin{array}{l}0 \\
0 \\
0 \\
0\end{array}$ & ले \\
\hline & 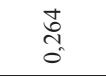 & $\stackrel{\tilde{C}}{0}$ & Fo & +̊. & & $\begin{array}{l}\text { oे } \\
\text { o. }\end{array}$ & $\begin{array}{l}\text { ๙ิ } \\
\text { ô }\end{array}$ & & $\overrightarrow{\sigma_{0}}$ & సั \\
\hline & & & & & & & $\overrightarrow{\sigma_{0}}$ & & & \\
\hline & & & & & & & $\begin{array}{l}\infty \\
\stackrel{0}{0} \\
0\end{array}$ & & & \\
\hline & $\begin{array}{l}\text { ते } \\
\text { Oे } \\
0\end{array}$ & $\begin{array}{l}\tilde{N} \\
0 \\
0\end{array}$ & & & $\begin{array}{l}\tilde{\sigma} \\
\text { है }\end{array}$ & 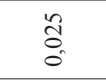 & $\begin{array}{l}\infty \\
\hat{0} \\
0 \\
0\end{array}$ & & & \\
\hline & $\begin{array}{l}\infty \\
0 \\
0 \\
0\end{array}$ & $\stackrel{\infty}{\stackrel{\infty}{0}}$ & $\begin{array}{l}\vec{\infty} \\
0\end{array}$ & $\begin{array}{l}\infty \\
0 \\
0\end{array}$ & $\hat{o}_{0}$ & 항 & Ŝ & $\frac{t}{0}$ & $\begin{array}{l}\infty \\
\stackrel{0}{0}\end{array}$ & $\begin{array}{l}\hat{E} \\
\text { o }\end{array}$ \\
\hline & $\stackrel{\tilde{z}}{\tilde{\sigma}}$ & ले & r. & $\stackrel{\infty}{0}$ & $\frac{\check{\sigma}}{0}$ & $\begin{array}{l}\tilde{y} \\
\tilde{\sigma}\end{array}$ & $\frac{\pi}{0}$ & 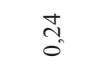 & 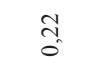 & $\frac{9}{0}$ \\
\hline$\dot{\underline{\theta}}$ & \begin{tabular}{l}
$\infty$ \\
\multirow{2}{*}{} \\
0
\end{tabular} & fิ & fo & f & $\begin{array}{l}n \\
\text { के } \\
\text { के }\end{array}$ & $\begin{array}{l}\infty \\
\stackrel{5}{f} \\
0\end{array}$ & 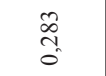 & $\stackrel{m}{0}$ & \begin{tabular}{l}
0 \\
\multirow{0}{*}{} \\
0
\end{tabular} & $\begin{array}{l}0 \\
\stackrel{0}{0} \\
0\end{array}$ \\
\hline 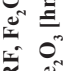 & $\underset{i}{i}$ & $\begin{array}{l}\stackrel{n}{n} \\
\text { i }\end{array}$ & $\begin{array}{l}\text { ¿̊ } \\
\text { i }\end{array}$ & $\stackrel{\tilde{n}}{\tilde{n}}$ & $\begin{array}{l}\stackrel{0}{\infty} \\
i\end{array}$ & î & $\begin{array}{l}\stackrel{2}{i} \\
\text { in }\end{array}$ & $\tilde{i}$ & $\stackrel{n}{\circ}$ & $\stackrel{\Rightarrow}{m}$ \\
\hline 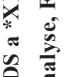 & $\frac{n}{0}$ & $\vec{\infty}$ & & & $\overrightarrow{0}$ & r. & $\stackrel{2}{0}$ & & $\hat{\hat{\sigma}}$ & $\frac{\infty}{0}$ \\
\hline 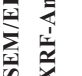 & 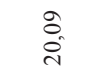 & $\begin{array}{l}n \\
\tilde{o} \\
\hat{i}\end{array}$ & $\begin{array}{l}\text { ț } \\
\stackrel{\text { iे }}{ }\end{array}$ & $\hat{=}$ & $\begin{array}{l}\tilde{N} \\
\infty \\
\stackrel{\sim}{1}\end{array}$ & $\begin{array}{l}\text { ते } \\
\text { ڤे }\end{array}$ & $\begin{array}{l}n \\
\infty \\
\stackrel{\sim}{n}\end{array}$ & $\hat{a}$ & $\begin{array}{l}\hat{5} \\
\stackrel{-}{0}\end{array}$ & $\begin{array}{l}\infty \\
\infty \\
\infty\end{array}$ \\
\hline 承 & $\begin{array}{l}\hat{6} \\
0 \\
0\end{array}$ & $\begin{array}{l}\infty \\
\infty \\
\dot{ \pm}\end{array}$ & $\begin{array}{l}\approx \\
\check{\eta}\end{array}$ & $\stackrel{ }{\circ}$ & $\begin{array}{l}\bar{ડ} \\
\triangleq\end{array}$ & $\begin{array}{l}\stackrel{2}{0} \\
\stackrel{0}{6}\end{array}$ & $\stackrel{n}{\infty}$ & $\begin{array}{l}\text { a } \\
\text { తi }\end{array}$ & 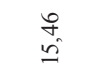 & $\stackrel{\infty}{\sim}$ \\
\hline 商 & \begin{tabular}{l} 
त \\
\multirow{2}{*}{}
\end{tabular} & $\begin{array}{l}\text { gे } \\
\text { oे }\end{array}$ & $\hat{\widehat{c}}$ & $\begin{array}{c}\infty \\
\tilde{c}_{0} \\
0\end{array}$ & $\begin{array}{l}\infty \\
0 \\
0 \\
0 \\
0\end{array}$ & $\hat{g}$ & ڤn & ริ & $\stackrel{n}{0}$ & స્ \\
\hline 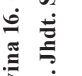 & $\begin{array}{l}n \\
i n\end{array}$ & $\begin{array}{l}n \\
n \\
i n\end{array}$ & $\begin{array}{l}\infty \\
\tilde{c}_{0} \\
8\end{array}$ & $\begin{array}{l}30 \\
8 \\
8\end{array}$ & $\begin{array}{l}\hat{n} \\
\tilde{n}\end{array}$ & ले & $\begin{array}{l}\text { I } \\
\text { ñ } \\
n\end{array}$ & $\begin{array}{l}n \\
\text { î }\end{array}$ & $\begin{array}{l}\stackrel{2}{8} \\
8\end{array}$ & $\begin{array}{l}\text { ô. } \\
\text { î }\end{array}$ \\
\hline 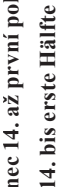 & $\sum^{5}$ & 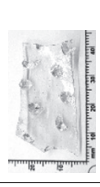 & 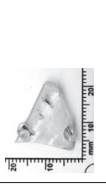 & (4) & 的 & 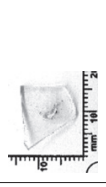 & दिवा & E. & 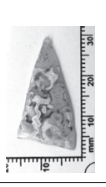 & $(8)$ \\
\hline 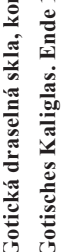 & 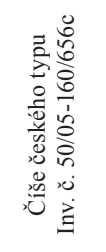 & 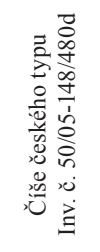 & 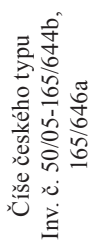 & 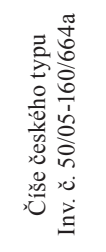 & 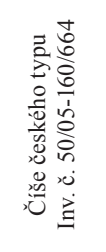 & 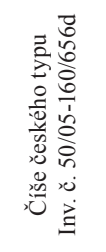 & 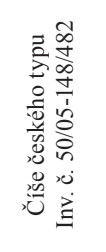 & 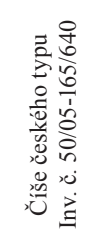 & 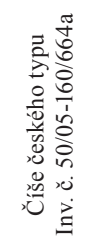 & 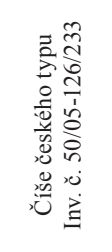 \\
\hline 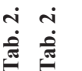 & ${ }_{*}^{\infty}$ & * & $\stackrel{\circ}{\gtrless}$ & $\bar{z}$ & $\underset{*}{\mathbb{*}}$ & $\underset{*}{*}$ & $\underset{*}{*}$ & $\frac{n}{\varangle}$ & $\frac{0}{4}$ & 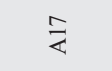 \\
\hline
\end{tabular}




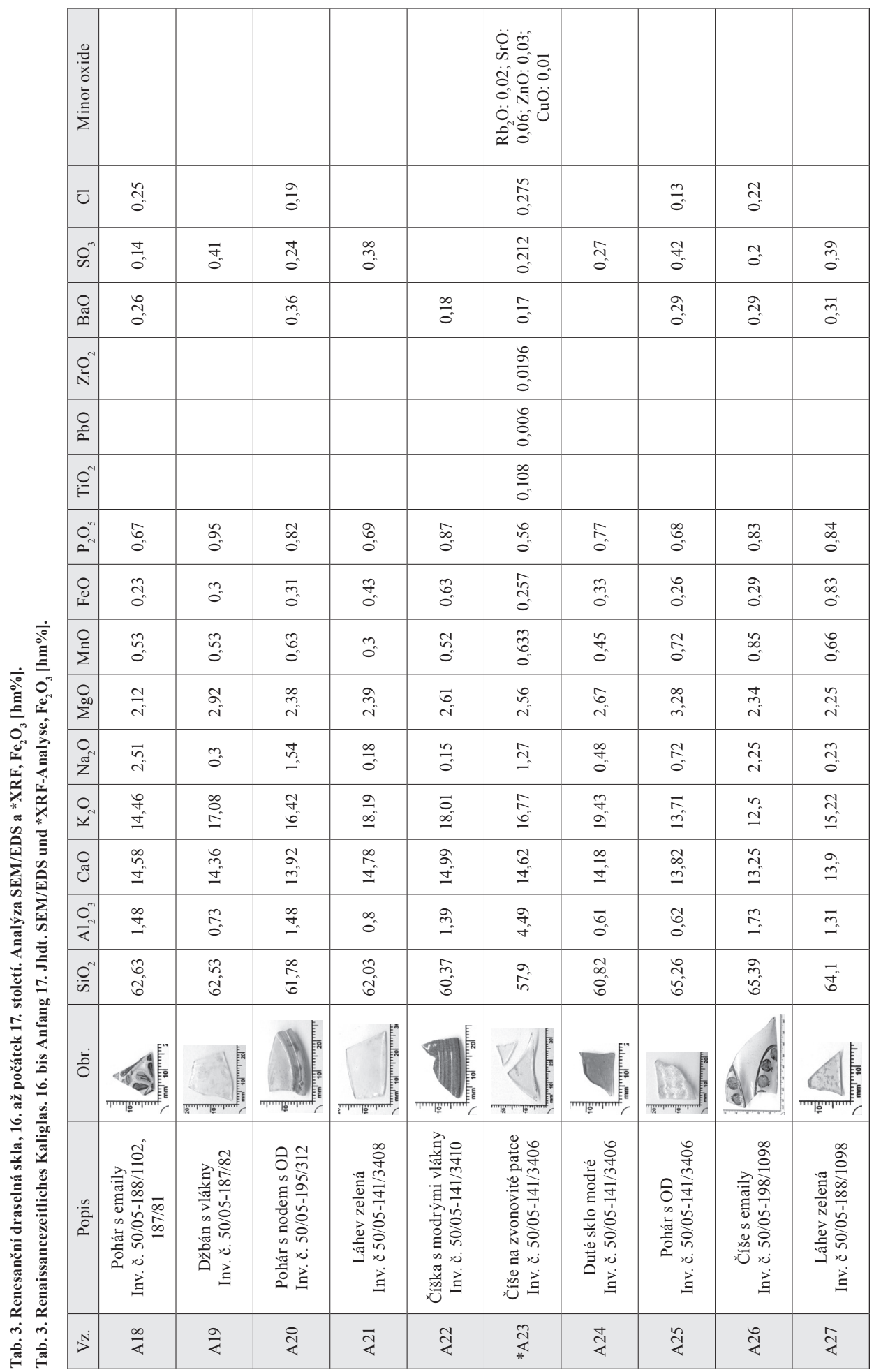


V mladší vrstvě 134 ležící nad s. j. 141 bylo nalezeno pouze zkorodované hrdlo láhve ovinuté zaštípanou lištou, jež zřejmě pochází ze stejné čočkovité láhve jako dno z vrstvy 141. Recentní prríměs představuje spodní část mírně kónické číšky s dekorem žeber a čoček z bezbarvého skla, která byla nalezena ve vrstvě 139 .

\section{Objekt 504}

Popis: odpadní jímka čtvercového půdorysu s vnitřní dřevěnou konstrukcí

Rozměry: $1,35 \times 1,4 \mathrm{~m}$, hloubka $5,2 \mathrm{~m}$

Výpln̆: Humózní až rašeliništní vrstvy s. j. 160, 157, 159, 149, 147, 144, 138 a 132 uzavřené ucpávkou z přemístěného podloží s. j. 118. Kromě skla, keramiky a dřevěných výrobků tvořily výplň fekální a rostlinné makrozbytky. Zajímavým nálezem je dřevěná trojdílná miska (slánka).

Datace: 15. století (dendrodata z výdřevy: 1403, 1405; z výplně: 1425/1426)

Literatura: Břečková a kol. 2018, 222; Kiecoň-Zezula 2007, 12; 2007a, 496; Rybníček 2007; Sedláčková 2011a, obr. 177:2 na s. 778

Popis skel: Z této jímky byla získána rozsáhlá kolekce skleněných nádob číající minimálně 35 jedinců. V nejstarší vrstvě 160 ležící u dna jímky byly nalezeny četné fragmenty středověkých číší českého typu zdobených převážně drobnými srpečkovými nálepy, méně často nálepy svinutými (obr. 4:1-2, 4-9, 11-14; tab. 2:A8, A11-A13, A16). Všechny číše z této vrstvy náleží vysoké štíhlé píšt’alovité variantě, která v Opavě i celém českém Slezsku představovala ve 14. a 15. století nejčastější typ skla. Minimální počet číší je na základě spodních částí odhadován na 27 jedinců. Pokud bylo možné určit původní barvu skla, byly číše vyrobeny ze skla lehce nazelenalého zbarvení. Bohužel ani u jedné z čiší nebylo možné sestavit celý profil, ale na základě částečně rekonstruovaných exemplářů lze jejich původní výšku odhadnout na $40-50 \mathrm{~cm}$. Na patkách jsou často patrné obloukovité nebo hrotité otisky po kleštích používaných při tvarování nádob. Kromě čiší českého typu obsahovala tato vrstva torza dvou neidentifikovaných nádob z nazelenalého skla bez koroze, jež pravděpodobně mohly sloužit laboratorním účelům (obr. 4:17-18), a zlomky láhve s vnitřním prstencem z bezbarvého skla (obr. 4:15). Láhve s vnitřním prstencem z bezbarvého a hnědého skla jsou v Opavě doloženy již od 13. století. Na Drůbežím trhu byly zachyceny i v dalších objektech, a to v jímkách 505, 508 a 534.

Nad vrstvou 160 ležela uloženina 157, z níž pochází několik dalších zlomků číší českého typu s drobnými srpečkovými nálepy a číše s diagonálními vlákny promačkávanými rádélkem (obr. 4:3). S tímto dekorem se však v opavských souborech více setkáváme až ve druhé polovině 15 . století. Z vrstvy 138 ležící v horní části výplně jímky bylo získáno torzo nádoby velkého průměru s mírně zataženým ústím (ca 11-11,5 cm; obr. 4:16). Horní část podobné číše byla nalezena v odpadní jímce 515 spolu se zlomky renesančního skla. Na tuto vrstvu nasedala uloženina s. j. 132, která obsahovala pouze několik zlomků skla, a to fragmenty číše českého typu zdobené vlákny promačkávanými rádélkem, zkorodované dno nádoby a další neurčitelné fragmenty nápojového skla.

\section{Objekt 505}

Popis: jímka čtvercového půdorysu s vnitřní dřevěnou konstrukcí

Rozměry: $1,65 \times 1,7 \mathrm{~m}$, hloubka $1,35 \mathrm{~m}$

Výplň: Výplň jímky tvořily vrstvy s. j. 150, 148, 146, 145, 120 a 124. Vedle kuchyňského odpadu a rostlinných makrozbytků obsahovala jímka soubor keramiky, fragmenty dřev, kủže a skla. 


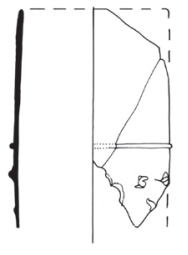

1

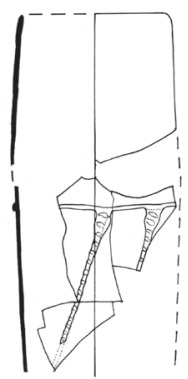

3

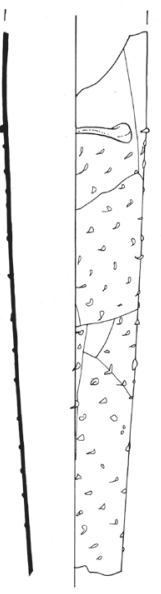

5

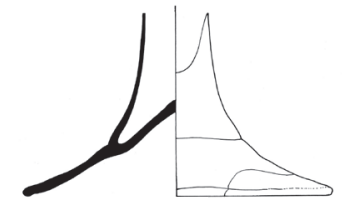

12

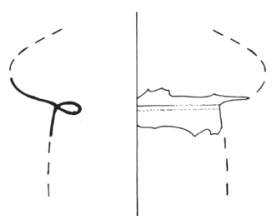

15

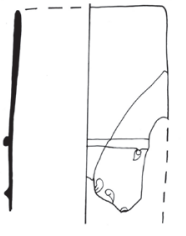

2

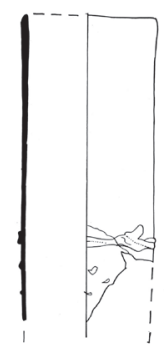

4

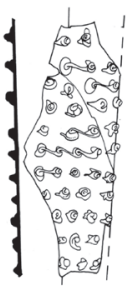

6

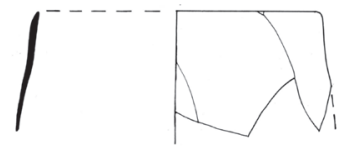

16

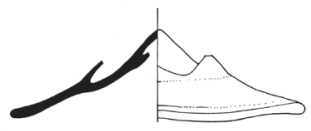

13

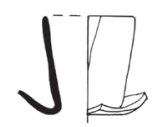

17
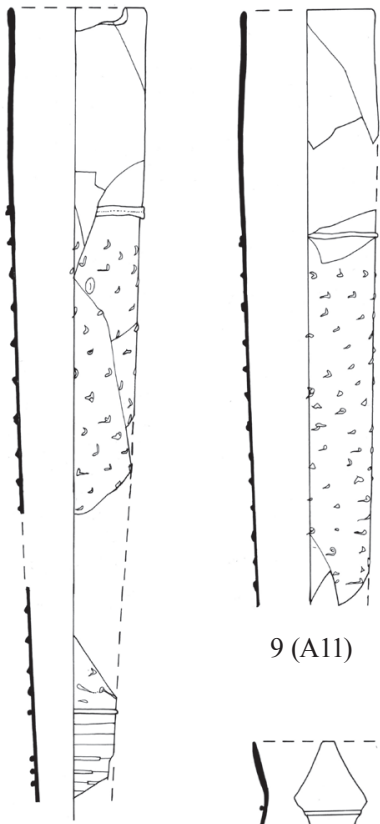

9 (A11)

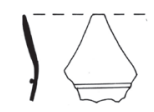

10

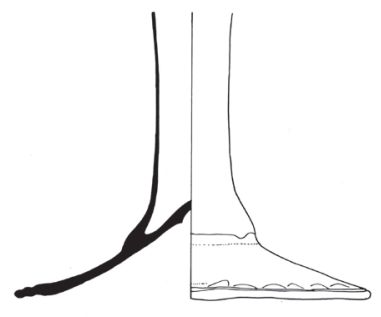

11

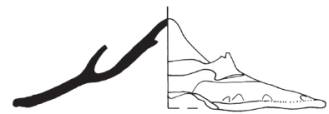

14

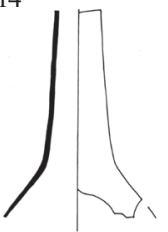

18

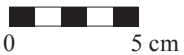

Obr. 4. Skleněné nálezy z jímky 504.

Abb. 4. Glasfunde aus Grube 504. 
Datace: $14 . / 15$. - první polovina 15. století

Literatura: Kiecoň-Zezula 2007, 12; Sedláčková 2011a, obr. 176:3 na s. 777

Popis skel: Skleněné fragmenty byly nalezeny ve spodní polovině výplně jímky, a to ve vrstvách 146, 148 a 150. Ve vrstvě 150 ležící u dna jímky byla zachycena torza minimálně dvou až tř́ vysokých číší českého typu se svinutými nálepy (obr. 5:4-5, 9), několik zkorodovaných skleněných okenních terčíků s přehnutým i jednoduchým zataveným okrajem a tabulky z nazelenalého skla. Některé ze zkorodovaných okenních výplní byly zdobeny konturovou malbou švarclotem (obr. 5:12), původní motiv se však vzhledem k drobným rozměrům nepodařilo rekonstruovat.

Nejméně jedenáct dalších nádob bylo získáno z následující vrstvy 148. Nejvíce zlomků náleží číším českého typu, z nichž se podařilo rekonstruovat deset exemplářů píštalovitého tvaru zdobených nepravidelnými svinutými až srpečkovými nálepy (obr. 5:1-3, 6, 8, 10; tab. 2:A9, A14). Dvě z číší se srpečkovými až mírně svinutými nálepy se podařilo rekonstruovat téměř celé a bylo tak možné odhadnout původní výšku, jež se blížila $50 \mathrm{~cm}$. Kromě uvedených číší zde byla nalezena láhev s vnitřním prstencem, která však na rozdíl od exempláře z jímky 504 dosahovala větších rozměrů a byla vyrobena ze skla hnědé barvy (obr. 5:7). Láhve s vnitřním prstencem z hnědého skla jsou v českých zemích doloženy především ve 13. a první polovině 14. století (Sedláčková ed. 2019a, 73-95). Vzhledem k dataci jímky by se tak jednalo o jeden z nejmladších dokladů používání láhví s vnitřním prstencem z takto zbarveného skla. Vrstva obsahovala také velké množství zlomků okenních tabulek se zatavenými okraji nebo zaštípanými hranami z nazelenalého skla (obr. 8; tab. 2:A5), některé však byly silně postiženy korozí. Tabulky byly vyrobeny z draselno-vápenatého skla podobného složení jako výrobky regionálních skláren. Z mladší vrstvy 146 pochází pouze spodní část a několik fragmentů výdutí číši českého typu se srpečkovými nálepy (obr. 5:11).

\section{Objekt 508}

Popis: jímka čtvercového půdorysu, vydřevená

Rozměry: $1,6 \times 1,7 \mathrm{~m}$, hloubka 3,8 m

Výplň: Jímka 508 byla zaplněna uloženinami 173, 169, 166, 165 a 126. Při jejím dně byl zachycen pozůstatek odpadní jímky 514, s níž byla v superpozici. Kromě souboru keramiky obsahovala jímka v horní části planýrovací odpad, fekální odpad a rostlinné makrozbytky.

Datace: první polovina 15. století (dendrodata z výplně: po roce 1390)

Literatura: Kiecoň-Zezula 2007, 13; Rybníček 2007; Sedláčková 2011a, obr. 176:1-2 na s. $776-777$, obr. $177: 1$ na s. 778

Popis skel: Z této jímky byl získán nejrozsáhlejší soubor skla sestávající převážně z nádob gotického tvarosloví, především číší českého typu, a několika nádob z období renesance. Skleněné fragmenty, které náleží nejméně 41-46 jedincům, byly získány ze všech vrstev výplně jímky. Ze spodní vrstvy 175 pocházejí zlomky dvou drobných lahviček (obr. 6:9) a fragmenty dutého skla, $\mathrm{z}$ nichž některé představují v této vrstvě mladší příměs. Jedná se o spodní část válcovité číše na duté zvonovité patce (obr. 6:12), torzo poháru s polovejčitou kupou zdobenou optickým dekorem (obr. 6:13) a jednoduchý pohár s hladkou kupou, tyčinkovým dříkem a patkou ze svinutého vlákna (obr. 6:14). Tento typ pohárů i číše na duté zvonovité patce patří již mezi skla renesančního tvarosloví a byly rozšířené především ve druhé polovině 16 . a v 17. století.

Další nádoby pocházejí z následující vrstvy 173, ze které bylo získáno nejméně deset píšt’alovitých číši českého typu zdobených v naprosté většině svinutými nálepy (obr. 6:6). Č́šš jsou 


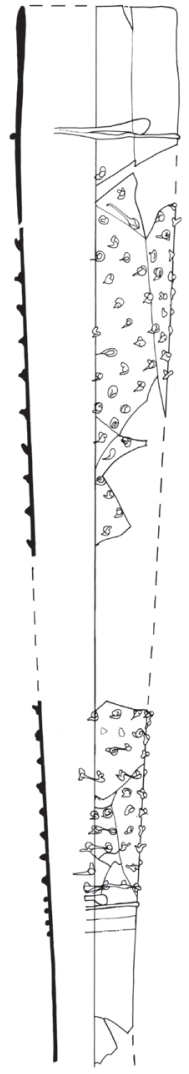

1 (A9)

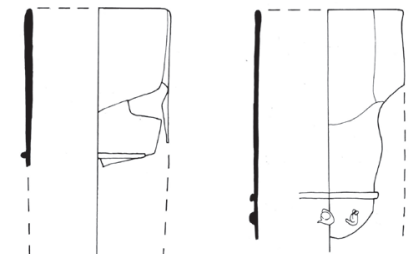

4

b) 1

का ।

900

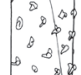

$\begin{array}{lll}0 & 0 \\ 8 & 2 & 5\end{array}$

2

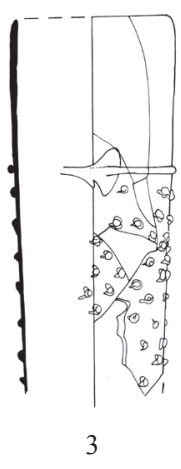

3

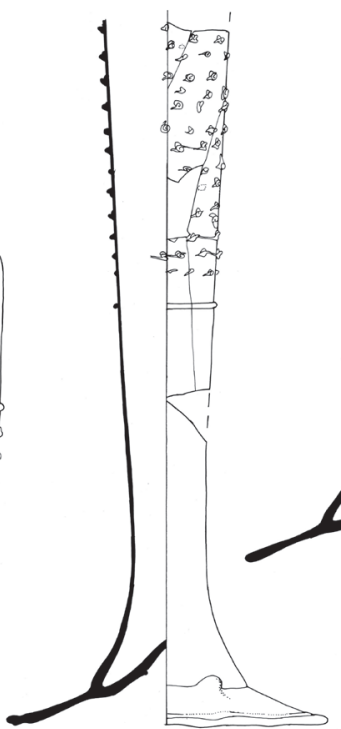

5

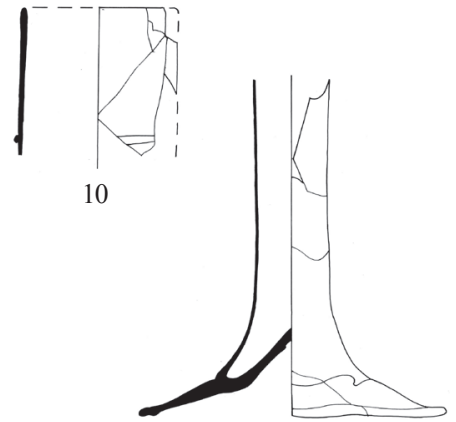

11

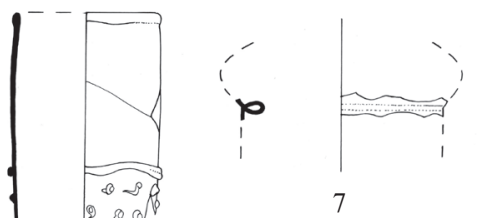

7
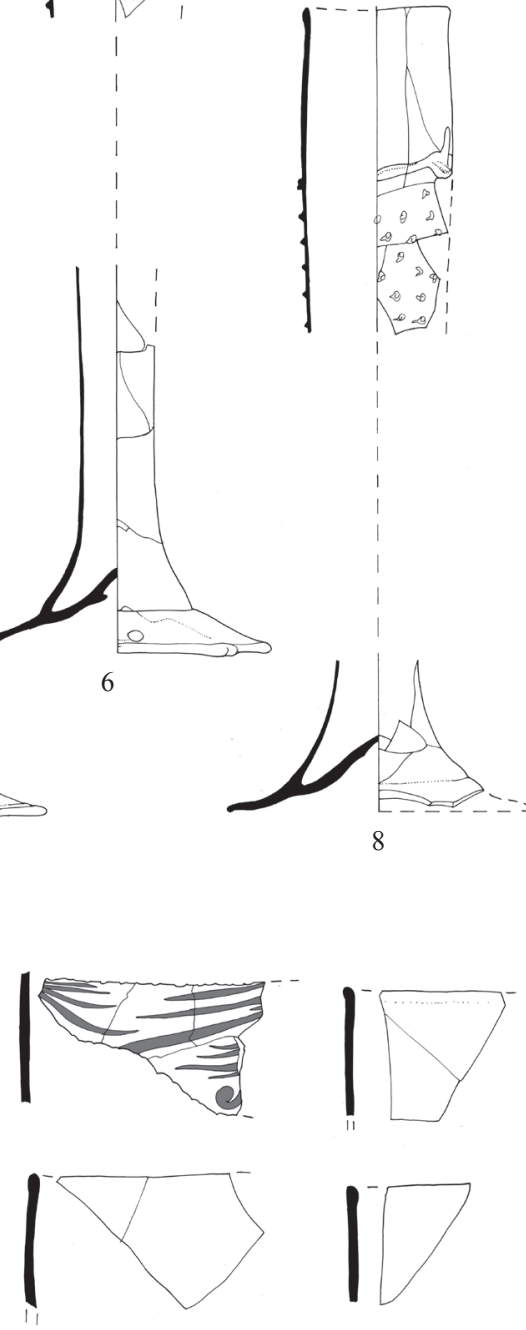

12 (A5)

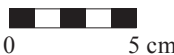

Obr. 5. Skleněné nálezy z jímky 505.

Abb. 5. Glasfunde aus Grube 505. 


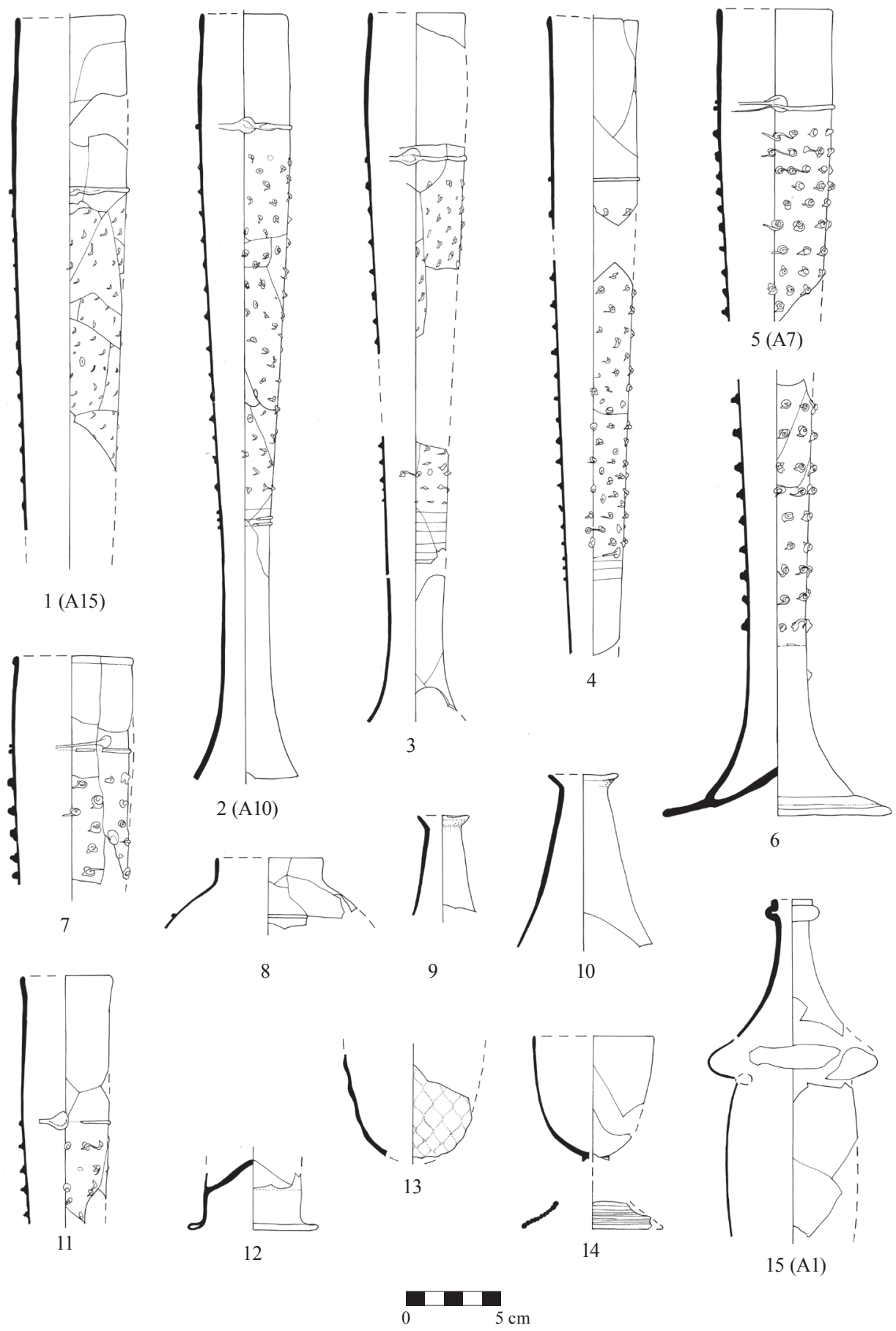

Obr. 6. Skleněné nálezy z jímky 508.

Abb. 6. Glasfunde aus Grube 508. 
vyrobeny z lehce nazelenalého až téměř bezbarvého skla. Ke stolnímu sklu určenému k servírování nápojů patř́i láhev s hruškovitým tělem z nazelenalého skla (obr. 6:10) a láhev s vnitřním prstencem, s vývalkem na hrdle a s mírně soudkovitým tělem (obr. 6:15; tab. 1:A1). Tato láhev je vyrobena z kvalitního bezbarvého sodno-popelového skla blízkého sklům benátským a v Opavě tak představuje import, stejně jako další láhve tohoto typu. Početná kolekce skleněných nádob byla vyzvednuta i z vrstvy 169 zabírající téměř dvě třetiny jímky. Vrstva obsahovala zkorodované zlomky okenní tabulky a torza minimálně dvanácti číší (počítáno podle patek, podle horních částí jich zde mohlo být až 22) se svinutými nálepy a nižším ústím (obr. 6:5, 7; tab. 2:A7). Zlomky dalších dvou až tří číší českého typu byly vyzvednuty ze stratigraficky mladší vrstvy 166. Tyto číše se od starších exemplářů liší provedením nálepů, které již nejsou pečlivě svinuté, ale srpečkovité.

Další tři patky a horní části nejméně sedmi píšt’alovitých číší zdobených nepravidelnými svinutými až srpečkovými nálepy byly získány z vrstvy 165 (obr. 6:1-4; tab. 2:A10, A15). Mezi méně časté nálezy patří torzo číše s výrazným kyjovitým zduřením pod okrajem (obr. 6:8). V horní vrstvě 126 uzavírající výplň jímky byly zachyceny zlomky nejméně tř́i číší se srpečkovými až čárkovitými nálepy a vysokým ústím (obr. 6:11; tab. 2:A17).

$\mathrm{V}$ případě několika číší českého typu z této odpadní jímky bylo možné rekonstruovat větší torza, na jejichž základě lze určit, že původní výška nádob dosahovala $40-50 \mathrm{~cm}$, podobně jako tomu bylo u číší z objektu 504. Výška ústí se pohybovala v rozmezí 3,6-10,4 cm, přičemž nižší ústí měly číše se svinutými nálepy.

\section{Objekt 510}

Popis: odpadní jímka s vnitřní dřevěnou konstrukcí, narušila starší jímku 534

Výplň: Vrstvy s. j. 176, 172, 171, 168, 167, 164 a 135, do jejíhož ústí byla zapuštěna vápenná jáma. Kromě množství keramických nádob jímka obsahovala i soubor kachlů s reliéfně zdobenou čelní stěnou.

Datace: 15 . století s přesahem do 16. století (dendrodata z výplně: po roce 1464, 1469 a 1489)

Literatura: Kiecoň-Zezula 2007, 12; Pavelková 2008, 39; Rybníček 2007

Popis skel: Z této jímky byl z vrstev 164, 171, 172 a 176 získán nepř́iliš početný soubor skleněných fragmentů čtyř až pěti nádob a zlomky okenního skla. Ve vrstvě 176 bylo kromě neurčitých drobných zlomků nalezeno dno nádoby z bezbarvého skla, pravděpodobně láhve, a fragmenty číše se svinutými nálepy z lehce nazelenalého skla. Vrstva 172 obsahovala zlomky okenních tabulek a terčíků s jednoduchým zataveným okrajem, dno láhve z nazelenalého skla a zkorodované dno další nádoby. Z láhve pochází také hrdlo zdobené jemnými optickými žebry z vrstvy 171 . Ve vrstvě 164 bylo zastoupeno prredevším sklo okenní, a to zlomky terčíků s přehnutým okrajem ze skla bezbarvého, nazelenalého nebo zcela zkorodovaného.

\section{Objekt 514}

Popis: odpadní jímka čtvercového půdorysu s vnitřní dřevěnou konstrukcí zachycená na dně mladší jímky 508

Výplň: s. j. 174

Datace: středověk

Literatura: Kiecoň-Zezula 2007, 13 
Popis skel: Z této odpadní jímky bylo získáno pouze několik zkorodovaných zlomků těla, patky a okraje číše českého typu zdobené pečlivě svinutými nálepy.

\section{Objekt 515}

Popis: odpadní jímka čtvercového půdorysu

Výplň: Jímka obsahovala vrstvy s. j. 230, 192, 190, 195, 188 a 109, uzavírala ji vrstva 187. Vedle keramiky a skla obsahovala dřevěné výrobky, mezi nimiž byly například skládané a soustružené misky.

Datace: 15.-16. století

Literatura: Kiecoň-Zezula 2007, 13; 2007a, 496

Popis skel: Z jímky 515 byl získán druhý nejpočetnější soubor skla na Drůbežím trhu čítající nejméně 39 nádob středověkého a raně novověkého stáří. Z vrstvy 230 na dně jímky bylo vyzvednuto pouze několik skleněných fragmentů, mezi nimi zkorodovaný okraj číše. Nad ní ležící vrstva 192 obsahovala také pouze několik skleněných nálezů, a to zkorodované dno a zlomky těla číšky nebo láhve s natavenými žebry (obr. 7:5) a torzo číšky zdobené vlákny a taženými kapkami, která byla vyrobena z binárního olovnatého skla žluté barvy (obr. 7:3; tab. 1:A4). Nádoby tohoto složení jsou v českých zemích vzácné, podobné složení bylo zjištěno u číšky ze Smilova Hradiska (Sedláčková ed. 2019, 162; tab. 7:A11a), nádob z Mostu a pražského Ungeltu z poloviny 13. až počátku 14. století (Černá 2000, 53).

V mladší vrstvě 190 bylo nalezeno množství zkorodovaných fragmentů vysokých píštalovitých číší českého typu zdobených svinutými nálepy. Na základě spodních částí je jejich počet odhadován nejméně na devět až deset jedinců (obr. 7:1-2). Nad ní ležící vrstva 195 obsahovala pouze několik fragmentů výdutí z bezbarvého skla a torzo renesančního poháru s nodem zdobeným optickým dekorem lvích maskaronů (obr. 7:17; tab. 3:A20). Další pohár se lvími maskarony a girlandami s květy byl nalezen ve vrstvě 187 (obr. 7:18). Na rozdíl od prvního exempláře, jenž představuje spíše zjednodušenou či nezdařenou imitaci původního vzoru, je u poháru z vrstvy 187 motiv proveden mnohem precizněji.

Početný soubor skla renesančního tvarosloví obsahovala vrstva 188. Nápojové sklo představují torza čtyř pohárů s různě tvarovanými kupami (obr. 7:7-8, 14) a nejméně tři číše na duté zvonovité patce. Jedna z číší byla zdobená malbou emaily s motivem konvalinek, jezdce na koni a neúplným letopočtem (původně zřejmě „158(?)“; obr. 7:11). V horní části pod okrajem je horizontální zlacený pruh ohraničený dvěma barevnými pruhy a bordurou z teček. Číše byla vyrobena z lehce našedlého skla draselno-vápenatého složení s př́ídavkem $\mathrm{NaCl}$ (tab. 3:A26). Z poháru nebo číšky pochází i patka ze spirálovitě svinutého vlákna (obr. 7:12). K servírování či ke skladování tekutin sloužily láhve s hruškovitým tělem a s dutým prstencem kolem dna, kterých bylo ve vrstvě nalezeno nejméně pět (obr. 7:9, 20; tab. 3:A27). Lišily se rozměry a odstínem skloviny. Soubor uzavírají okenní terčíky s přehnutým okrajem a trojúhelníkovité výplně se zaštípanými hranami.

Svrchní vrstva výplně jímky, s. j. 187, obsahovala již zmiňovaný pohár se lvími maskarony a torzo poháru s nálevkovitou kupou zdobenou emaily (obr. 7:15; tab. 3:A18). Kolem okraje je pás bílých konvalinek, což byl v Čechách i ve Slezsku velmi oblíbený motiv, pod ním se nachází bordura z teček a zlacený pruh. Kupa je vertikálními liniemi rozčleněna do několika částí, které jsou dále rozděleny do mřižky, jejíž jednotlivá pole jsou vyplněna květy. Tento dekor je unikátní a zatím nebyly nalezeny žádné analogie. Kromě tohoto luxusního nápojového skla vrstva obsahovala i běžné vybavení domácnosti, a to minimálně dvě láhve s hruškovitým tělem, čtyřbokou láhev (obr. 7:16) a dvě číše na duté zvonovité patce (obr. 7:13). Mezi méně časté typy skla patří horní část nádoby s velkým průměrem (obr. 7:4) a torzo láhve nebo džbánu s kulovitým tělem spirálovitě ovinutým hladkým vláknem (obr. 7:19; tab. 3:A19). Tento motiv se uplatnil také na džbánech 


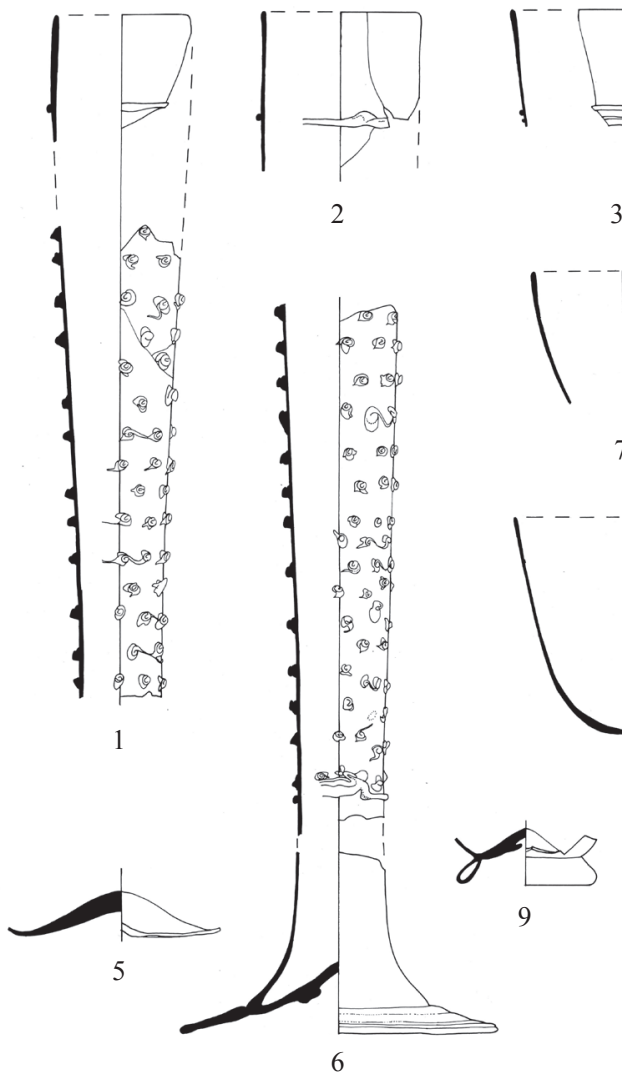

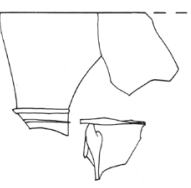

3 (A4)
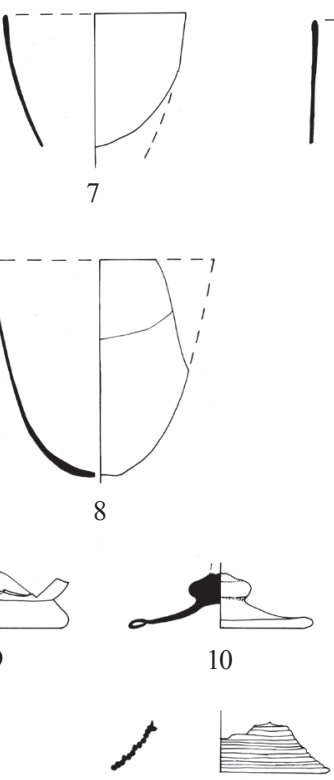

12

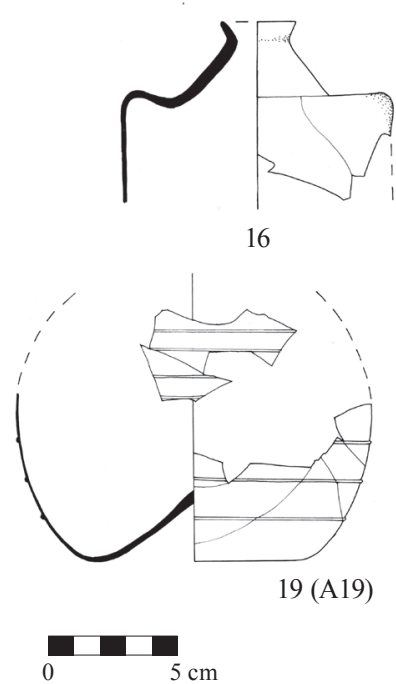

16

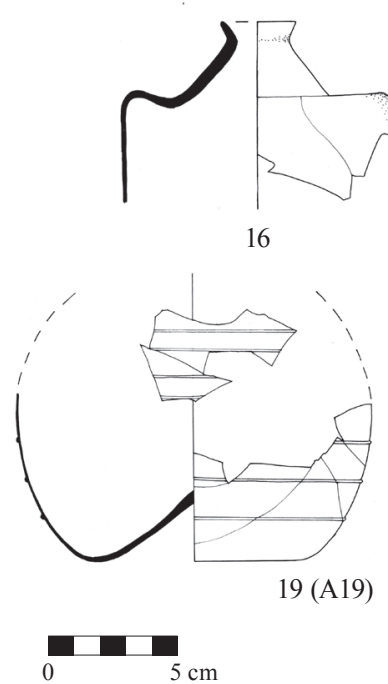

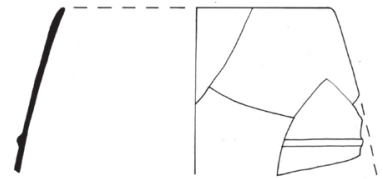

4
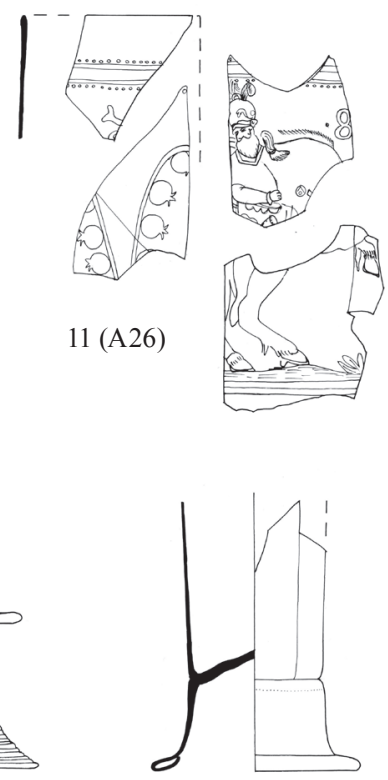

13
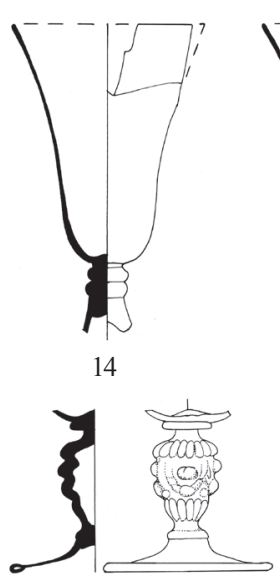

17 (A20)
18

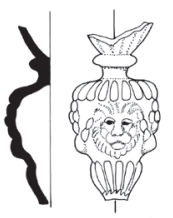

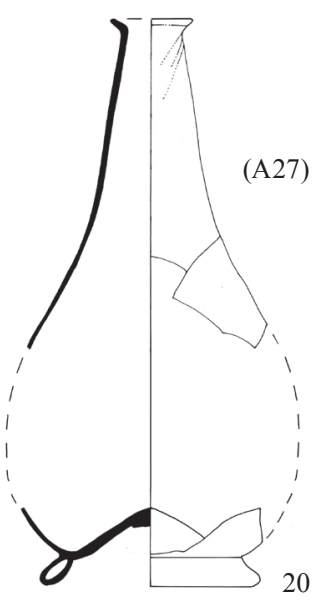

Obr. 7. Skleněné nálezy z jímky 515.

Abb. 7. Glasfunde aus Grube 515. 
v Čechách, např́iklad v Plzni (Frýda 2007; tab. 10:10 na s. 51), Praze (Drahotová a kol. 2005, 152, obr. 12) a Chrudimi, ale také v polském Slezsku (Nowosielska 2004, 76, ryc. 4:4 na s. 67).

\section{Objekt 534}

Popis: pravděpodobně čtvercová jímka s vnitřní dřevěnou konstrukcí, která byla zčásti narušená mladší jímkou 510

Rozměry: šířka 1,4 m, hloubka min. 3,7 m

Výplň: Jímka nebyla prozkoumána celá, odebrány byly pouze vrstvy s. j. 208, 217, 218, 219, 220 a 256, jež obsahovaly keramiku, fekální výplň a rostlinné makrozbytky.

Datace: druhá polovina 13. století

Literatura: Kiecoň-Zezula 2007, 12; Sedláčková 2011a, obr. 173:1 na s. 771

Popis skel: Sklo bylo v této jímce zastoupeno ve vrstvách 208, 219 a 220. Nejstarší sklo pochází z vrstvy 220 , která mimo jiné obsahovala vpíchnuté dno láhve s vnitřním prstencem z kvalitního hnědého skla vyrobeného ze sklářského kmene složeného z písku a popela solnomilných rostlin (tab. 1:A2).

Stratigraficky mladší vrstva 219 obsahovala zkorodované dno další nádoby, pravděpodobně láhve, a zlomek výdutě $\mathrm{z}$ tenkostěnného hnědofialového skla, který může také pocházet $\mathrm{z}$ láhve s vnitřním prstencem. Zasklívání oken domů opavských měštanů již ve 13. století dokládá nález okenní tabulky z bezbarvého skla z vrstvy 208. Na obou delších stranách tabulky jsou patrné stopy po řezání a jedna hrana je jemně zaštípaná. V tak časném období nepatří okenní sklo mezi běžné archeologické nálezy, více se objevuje až od druhé poloviny 14. století. V Opavě je okenní sklo z tohoto období doloženo na Dolním náměstí (Sedláčková 2011, 299). Ze stejné vrstvy pochází mozaiková kostka z opakního tmavého skla.

Z vrstvy 199 ležící nad jímkou 534 bylo vyzvednuto vpíchnuté dno pravděpodobně láhve a zlomky láhve s vnitřním prstencem vyrobené z lehce fialového skla. Na tuto vrstvu nasedá vrstva 198, z níž byla získána pouze část zkorodovaného dna nádoby.

\section{Objekt 561}

Popis: odpadní jímka s čtvercovým ústím a vnitřní dřevěnou konstrukcí

Výplň: souvrství humózních hlín s vysokým obsahem rostlinných makrozbytků (s. j. 380, 386, $413,414)$

Datace: 15. - počátek 16 . století

Literatura: Kiecoň-Zezula 2007, 14

Popis skel: Ze svrchní části výplně jímky, z vrstvy 380, byl získán pouze jeden zlomek tenkostěnného bezbarvého skla. Vzhledem k drobným rozměrům však nelze určit, z jaké nádoby pochází.

\section{Objekt 568}

Popis: odpadní jímka čtvercového půdorysu s vnitřní dřevěnou konstrukcí, která narušila starší zahloubený objekt 537 
Výplň: humózní a rašeliništní vrstvy hnědošedých až šedočerných barev (s. j. 429, 434, 435, 436, $437,438,439)$

Datace: konec 13. - 14. století (dendrodata z výdřevy: 1278/1279)

Literatura: Kiecoň-Zezula 2007, 16; Rybníček 2007

Popis skel: Jímka 568 obsahovala pouze několik velmi drobných fragmentů dutého skla. Z vrstvy 439 u jejího dna byl získán unikátní zlomek okraje nádoby z opakního bílého skla, který zůstává zatím bez analogií, a blíže neurčitelné zkorodované fragmenty dutého skla. V prŕípadě okraje z opakního bílého skla nelze vyloučit, že se jedná o novověkou příměs.

\section{Objekt 570}

Popis: odpadní jímka čtvercového půdorysu s vnitřní dřevěnou konstrukcí

Výplň: Humózní a rašeliništní vrstvy s. j. 463, 462, 432. Výplň nebyla odebrána celá, výzkum byl ukončen na úrovni s. j. 470.

Datace: konec 13. století (dendrodata z výdřevy: 1265/1266)

Literatura: Břečková a kol. 2018, 224, 227; Kiecoň-Zezula 2007, 16; Rybníček 2007; Sedláčková 2011a, obr. 173:2 na s. 771

Popis skel: Sklo bylo získáno pouze z uloženin 462 a 470. Ve stratigraficky starší vrstvě 470 byly nalezeny drobné zlomky okraje a výdutě číšky s optickým dekorem šikmých žeber, zatímco mladší vrstva 462 obsahovala mimo jiné kus červenohnědé opakní skelné strusky s četnými neprotavenými zrnky písku a fragment zkorodované okenní tabulky. Raně novověkou intruzi představuje zlomek vřetenovité kupy poháru z nazelenalého skla.

V realizovaných sondách bylo zachyceno sklo i ve vrstvách mimo výše uvedené objekty. V sondě S2 byly fragmenty středověkého a raně novověkého skla nalezeny v několika uloženinách. Zkorodované zlomky středověkého skla pocházejí z vrstvy 213, která patří do souvrství jílovito-prachových hlín překrývajících zahloubený objekt 528 . Ve vrstvě 385 , nad objekty 510 a 534 v úrovni s. j. 206 a v mladší vrstvě 200 byly nalezeny zlomky láhví s vnitřním prstencem z bezbarvého skla. Z poslední uvedené vrstvy bylo vyzvednuto i zkorodované dno nádoby a okenní tabulka z bezbarvého skla. Vrstva 185 byla na nálezy skla bohatší. Středověké sklo reprezentují zlomky číše českého typu se svinutými nálepy, $\mathrm{k}$ raně novověkému sklu patří dno láhve z nazelenalého skla a zlomky pohárů nebo číši ze skla bezbarvého. Okenní sklo je zastoupeno terčíky s přehnutým okrajem. Vzácným nálezem jsou zkorodované zlomky nádoby zdobené masivními žebry, které byly vyzvednuty z mladší vrstvy 184 spolu se zlomky téměř bezbarvého skla. Výše uvedené vrstvy 200, 185 a 184 byly součástí souvrství obsahujícího keramický materiál z konce 13. až 14. století. Několik zlomků číšek s hrotitými nálepy vyrobených z bezbarvého sodno-popelového skla (tab. 1:A3), láhve s vnitřním prstencem z bezbarvého skla a zlomek zkorodované číšky s velkým šnekovitým nálepem byly získány z vrstvy 177 ležící v horní části profilu u jímky 505. Unikátní nález představuje zlomek číšky oboustranně malované emaily (Sedláčková 2011a, obr. 171 na s. 769), jenž pochází z šedé jílovité vrstvy 371 ležící nad souvrstvím z konce 13. a průběhu 14. století překrývajícím jímku 563. Číšky oboustranně zdobené emaily byly ve středověku považovány za velmi luxusní zboží dostupné pouze nejvyšším společenským vrstvám.

V sondě S3 byly nalezeny fragmenty raně novověkého skla ve vrstvě 193 v těsné blízkosti odpadní jímky 505. Jedná se o zlomky těla a dno láhve s patkou tvořenou dutým prstencem, která je vyrobena $\mathrm{z}$ nazelenalého skla. 
Nepočetné fragmenty dutého i okenního skla byly získány z vrstev 239, 253, 296 a 339 v sondě S4. Z posledních dvou jmenovaných vrstev však byly vyzvednuty pouze zlomky terčíků s přehnutými okraji. Z vrstvy 239 pochází zlomek dna z nazelenalého skla a fragment zkorodovaného skla. Jedinečným nálezem je fragment nádoby, zřejmě misky, s masivním žebrem z kvalitního hnědého skla, který byl nalezen ve vrstvě 253 .

Středověké sklo ze sondy S5 reprezentují zlomky láhví s vnitřním prstencem z hnědého skla vyzvednuté z vrstev 225 a 279 (Sedláčková 2011a, obr. 170:3 na s. 768) a zkorodované okenní tabulky z vrstvy 326 . Ve vrstvě 420 a 453 byly nalezeny zlomky bezbarvého okenního skla a nádoby $\mathrm{z}$ hnědého čirého skla. Kromě výše uvedených nálezů byly v sondě zachyceny pouze neurčité skleněné fragmenty.

\section{Středověké sklo z 13.-15. století}

Nejstarší skleněné nálezy z Drůbežího trhu pocházejí již ze 13. století a kromě jímek 534 a 570 byly získány i z archeologických situací mimo zahloubené objekty. V tomto období představovaly skleněné výrobky luxusní zboží dostupné pouze vyšším společenským vrstvám - dobře situovaným měštanům, šlechtě a významným církevním hodnostářům. Také na této lokalitě, stejně jako i jinde v Opavě, mezi skleněnými nálezy z 13. až počátku 14. století naprosto převládají skla importovaná z vyspělejších sklářských oblastí. Jedná se především o zlomky láhví s vnitřním prstencem z hnědého až hnědofialového skla, méně ze skla bezbarvého. Několika zlomky jsou na Drůbežím trhu doloženy i číšky s nálepy vytaženými do hrotů z kvalitního bezbarvého skla sodno-popelového složení (tab. 1:A3). Tyto číšky byly velmi oblíbené na jižní Moravě, kde jsou jedním z nejčastějších typů nápojového skla. U obou těchto tvarů je uznáván jejich původ v benátských, respektive severoitalských sklárnách, což potvrdila i řada analýz moravských a slezských nálezů (Sedláčková ed. 2019, tab. 11 na s. 166-167; 2019a, 67-95, 122-143). Výroba sodno-popelového skla je však v pozdějším období doložena také v dalších oblastech jižní Evropy. Například sklářští mistřri z Dubrovníku byli schopni vyrobit nádoby z bezbarvého sodného skla téměř nerozeznatelné od výrobků z Murana (Stamenković 2015, 376-37). Analyzovaná láhev z hnědého skla vyzvednutá z odpadní jímky 534 se svým složením ovšem neshoduje s benátskými skly (tab. 1:A2) a její původ je tedy nutné hledat jinde. Sklo podobného chemického složení, které bylo vyráběno z popele ze solnomilných rostlin dováženého zřejmě z Levanty, bylo nalezeno v klášteře sv. Severa v Raveně (Vandini a kol. 2018, tab. 2). Zajímavý je u opavského exempláře poměr $\mathrm{MnO}$ a FeO, jenž činí zhruba $3: 1$. Stejný poměr těchto oxidů byl zjištěn u sodno-popelových skel barvených manganem z Brna a Bratislavy, což nasvědčuje tomu, že se $\mathrm{MnO}$ a FeO do skla dostaly ze stejného zdroje. Tímto zdrojem mohly být minerální suroviny z Umbrie nebo z lokalit, kde probíhala těžba železné rudy (Sedláčková a kol. 2014, 240, tab. 3a, 3b, 4a, 4b).

Ze stejně zbarveného skla byla vyrobena i nádoba s masivními žebry nalezená v sondě S4. Jedinou analogií z českých zemí je miska s výraznými žebry z Mečové ulice v Brně, která pochází z let 1270-1350 (Sedláčková 2006, fig. 4d na s. 203). Na rozdíl od opavského exempláře je však vyrobena z našedlého až nažloutlého skla a má analogie na Sicílii (Stiaffini 1999, obr. 177). Také v případě opavského exempláře je jistá cizí provenience, ale místo přesného původu zůstává neznámé. Do sortimentu benátského skla však bezesporu patří číška oboustranně malovaná barevnými emaily. Jejich výroba je doložena v Benátkách již mezi lety 1280-1350, odkud byly jako vysoce ceněný artikl vyváženy nejen do Evropy, ale i do Asie. V Opavě byla nalezena ještě jedna číška s emaily, a to na bývalé Radniční ulici ve vrstvě datované od konce 13. do poloviny 14. století (Skalická 2012, 66-67). Vzhledem k nízkému počtu těchto číšek v českých zemích je pravděpodobné, že opavské exempláře jsou důkazem spíše osobních kontaktů (dary, suvenýry $\mathrm{z}$ cest apod.) než obchodních vazeb.

Nálezy těchto skel na Drůbežím trhu v tak časném období dokládají velký obchodní potenciál opavských měšt’anů, kteří měli přístup k dováženému prestižnímu sklu. Vedle těchto nádob z kvalitního skla se na Drůbežím trhu již v kontextech 13. a 14. století objevují zkorodovaná torza 
skleněných nádob (číše a číšky s nálepy, s plastickými žebry nebo s optickým dekorem), jejichž původ lze hledat v českých nebo německých sklárnách.

Z odpadních jímek 504, 505, 508 a ze spodní části výplně jímky 515 byly získány početné soubory středověkého skla z přelomu 14. a 15. až průběhu 15 . století, v nichž naprosto dominovaly píšt’alovité číše českého typu zdobené svinutými nebo srpečkovými nálepy. Tento tvar nápojového skla je charakteristický pro výrobky středověkých skláren v českých zemích a v českém Slezsku byl ve 14.-15. století nejrozšířenějším typem dutého skla vůbec. Vzhledem k většímu objemu je předpokládáno jejich využití především ke konzumaci piva. Pouze jediným exemplářem je na Drůbežím trhu doložena číše výrazně kyjovitého tvaru, která má analogie např́íklad na Masařské ulici 6 (Břečková 2017, obr. 3:7 na s. 260). Více rozš́iřená však byla tato varianta číší v polské části Slezska. Zde jsou spolu s píštalovitými číšemi zobrazeny i na architektonické výzdobě radnice ve Vratislavi (Biszkont 2005, fot. 9-10 na s. 215). Analýzy vybraných číší potvrdily, že jsou zhotoveny ze skla draselno-vápenatého (tab. 2:A7-A17), jaké bylo v českých sklárnách vyráběno již ve 14. století. Na základě poměru alkalických složek $\mathrm{CaO}$ a $\mathrm{K}_{2} \mathrm{O}$ lze číše z Drůbežího trhu rozdělit do tř́ podskupin. Je tedy pravděpodobné, že na lokalitu byly dovezeny číše z několika regionálních skláren nebo přinejmenším číše vyrobené z různých zdrojů, či mírně odlišnými technologiemi. Podobné složení skla bylo zjištěno i u číší z dalších opavských lokalit (Břečková 2017, tab. 1-2 na s. 282).

Vedle číśí českého typu se sporadicky objevují i jiné typy nádob, například číšky a láhve. Na Drůbežím trhu však postrádáme další typický výrobek středověkých českých skláren, a tím jsou číšky s taženými kapkami. Tento jev není ovšem nijak překvapivý. V Opavě, ale i v celém českém Slezsku byl totiž na rozdíl od Čech tento tvar dutého skla rozšířen minimálně. Importované nádoby jsou $v$ těchto jímkách zastoupeny pouze jednotlivými kusy. V jímkách 504, 505 a 505 to jsou láhve $\mathrm{s}$ vnitřním prstencem, zatímco v jímce 515 představuje import unikátní číška z binárního olovnatého skla žlutého zbarvení (tab. 1:A4). Její původ lze pravděpodobně hledat v německých sklárnách, které vyráběly olovnaté sklo ve 12.-14. století. Binárního olovnaté sklo velmi podobného složení jako opavský exemplář je doloženo v Erfurtu (Mecking 2013, tab. 3 na s. 645). Archeologickými i písemnými prameny je produkce olovnatého skla zdokumentována v prostředí dolnosaských klášterů (Stephan-Wedepohl 1997). Kromě německých skláren však olovnaté sklo vyráběli i skláři v dalších zemích, např́íklad v Polsku (Černá-Hulínský-Gedeon 2001, 78, 81). Vzhledem k datování jímky tato číška zřejmě představuje starší př́íměs.

Vedle změny sortimentu a poměru importů a výrobků domácí provenience pozorujeme na Drůbežím trhu ve 14.-15. století výrazný nárůst počtu nádob oproti období předchozímu. Sklo se stalo dostupnější pro širší vrstvy měštanů, což dokládá i šíření okenního skla.

\section{Sklenářská dílna na Drůbežím trhu}

Významnou část středověké sklářské produkce představovalo okenní sklo, které se v Opavě objevuje již od 13. století. První konkrétní zpráva o zasklívání oken ve Slezsku pochází až z roku 1333 a váže se k augustiniánskému klášteru v Żagańi, již ve starších zmínkách z let 1317 a 1328 jsou však jmenovány sklářské výrobky v souvislosti s tržním a celním právem Lehnice. Od 14. století se v historických písemných pramenech objevují zmínky o obchodnících zásobujících slezská města skleněnými výrobky, o dodávkách okenního skla pro církevní i světské stavby i o sklenárích a maliřích skla provozujících své řemeslo ve městech. Sporadicky v pramenech figurují jména konkrétních sklářů či sklenářů působících na Moravě a ve Slezsku (např́íklad Czihak 1891, 4-5, 42-43; Lněničková 2004, 14).

Přestože na základě zmínek v historických pramenech můžeme předpokládat, že také ve středověké Opavě působili sklenáři a malíři skla, nebyly dosud pro jejich působení nalezeny žádné doklady. Nové světlo na tuto problematiku vrhá nález z odpadní jímky 505 na Drůbežím trhu, jež podle stabilního katastru náležela k domu čp. 319 v severovýchodní části ulice Mezi Trhy (Kiecoň-Zezula 2007, 6-7). V této odpadní jímce byl ve vrstvách 148 a 150 nalezen početný 
soubor okenního skla, který vedle devíti zlomků okenních terčíků s přehnutým i jednoduchým zataveným okrajem a několika zlomků vitrají zdobených malbou obsahoval přes 300 fragmentů nezdobených tabulí z nazelenalého skla, z nichž některé byly výrazně postiženy korozí. $Z$ jímky byly získány i fragmenty olověných profilů ve tvaru písmene $\mathrm{H}$, jimiž byly jednotlivé okenní segmenty spojovány.

Při bližším prozkoumání materiálu bylo zjištěno, že většina zlomků okenních tabulí má podobný pravidelný tvar a výrazně převažují velmi drobné a úzké fragmenty, s velkým podílem okrajových fragmentů. V získaném materiálu se podařilo identifikovat jak okrajové zlomky tabulí, které mají tvar kruhové úseče s jednou ostrou (odlomenou) obloukovitou hranou a druhou rovnou hranou, již tvoří zatavený okraj nebo také ostrá hrana (obr. 8:6), tak zlomky ve tvaru kruhové úseče s obloukovitým výřezem na rovné hraně (obr. 8:7) a zlomky srpečkovitého tvaru. Výjimečně se objevily větší okrajové zlomky se značně nerovnoměrnou tloušt'kou (obr. 8:1-4).

Jednotný tvar úlomků naznačuje, že se nejedná o odpad z běžné domácnosti, ale o doklad sekundárního zpracování okenního skla (tvary odštěpků byly srovnány s Kaufmann 2010, 113-123). Úzké zlomky s jedním okrajem zataveným a s druhou obloukovitou hranou představují výrobní odpad, jaký vzniká při úpravě tabulového skla. Na velké části tabulek jsou navíc zřetelné několikanásobné ryté linie, jimiž si sklenář na velkou okenní tabuli předrýsoval požadované tvary jednotlivých výsledných tabulek, aby tak při odštipování okrajů zabránil odlomení větší části tabule, než zamýšlel (obr. 8:2, 5, 7). Na hranách některých úštěpků lze pozorovat stopy po nástrojích vzniklé při jejich odlamování.

Tyto fragmenty okenního skla lze tedy interpretovat jako výrobní odpad z dílny sklenáře působícího na lokalitě v první polovině 15. století. Na základě analýz složení skla je pravděpodobné, že sklenář kupoval okenní sklo vyrobené cylindrickou metodou z některé z regionálních skláren a pak jej dále zpracovával (obr. 9; tab. 2:A5). Okrajové části tabulí vyrobených touto metodou byly silnější než střed, proto musely být upraveny. Sklenář si nejdříve na tabuli předrýsoval tvar výsledných tabulek, rozlámal ji a na jednotlivých tabulkách rytými liniemi vyznačil okraje, které měly být odštípány. Poté odštípal první linii úštěpků (s jednou hranou obloukovitou, druhou rovnou) a pak hranu retušoval odštípáním menších kousků (tyto odštěpky už nemají rovnou hranu). Hotové tabulky poté spojil pomocí olověných rámečků do požadované kompozice.

Vzhledem k nálezům několika tabulek zdobených malbou nelze vyloučit, že místní sklenár vyráběl vedle běžného tabulového skla i barevné sklo vitrajové. Okenní sklo zdobené malbou (vitraje) není u měšt’anských domů v Opavě př́liš běžné, objevuje se spíše v souvislosti s církevním prostředím. Středověké vitraje byly nalezeny např́íklad mezi ulicí Mnišskou a Mezi Trhy, ve vnitrobloku mezi Pekařskou a Kolářskou (Břečková 2017, 267, 271) a na Krnovské ulici. Okenní sklo zdobené malbou svědčí o vyšším společenském postavení majitelů těchto domů. Velmi početný soubor čítající několik set zlomků vitrají pochází z kostela sv. Václava u dominikánského kláštera (Vad’urová 2021, 149-151).

\section{Mezi gotikou a renesancí}

Zajímavý soubor dutého skla, v němž se mísí prvky pozdně gotické a renesanční, byl získán zjímky 500 zaplňované v průběhu 15.-16. století. Soubor skla při srovnání s materiálem z Moravy a Slezska lze datovat spíše až do druhé poloviny až závěru 15. století a do průběhu století následujícího. Nádoby gotického a renesančního tvarosloví lze rozlišit nejenom na základě typologie, ale také podle charakteru skla, ze kterého jsou vyrobeny. Kromě chemických analýz je lze rozlišit i opticky, nebot' skla vyrobená podle gotické receptury výrazněji podléhají korozi.

Ke sklu pozdně gotickému patří číše se štíhlou nožkou, číšky se dnem ovinutým vláknem, ale také zkorodované láhve se žebry a konvička nebo džbánek s modrým vláknem v okraji. Některé z těchto nádob jsou zdobené optickým dekorem vzniklým vyfouknutím baňky skla do formy a následným dotvarováním nádoby. Přestože se tento dekor objevuje již na skle vrcholně středověkém, častěji se s ním v českém Slezsku setkáváme až od druhé poloviny 15. století 

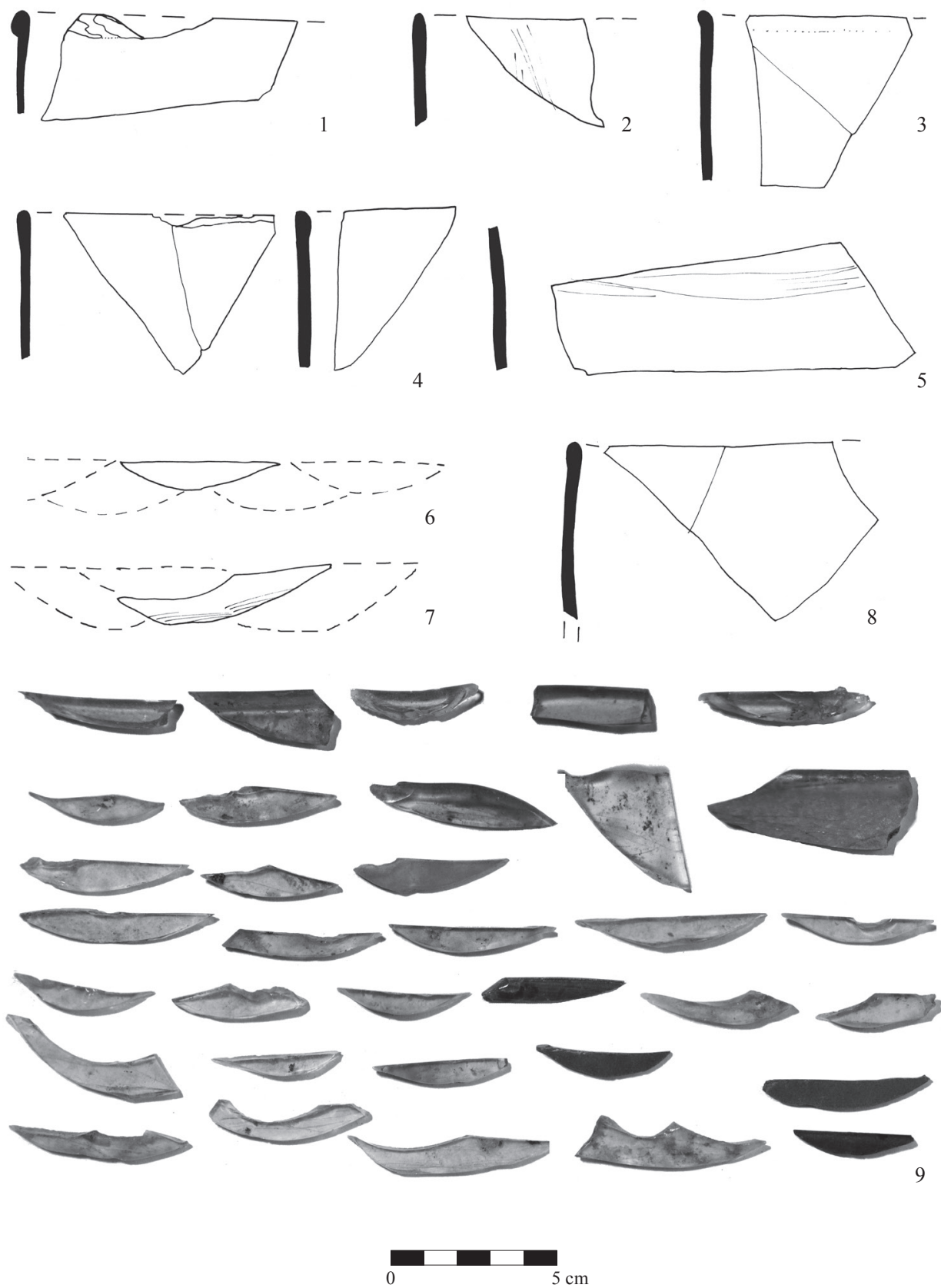

Obr. 8. Výrobní odpad po zpracování okenních tabulí z odpadní jímky 505.

Abb. 8. Produktionsabfall von der Bearbeitung von Fensterscheiben aus Abwassergrube 505. 


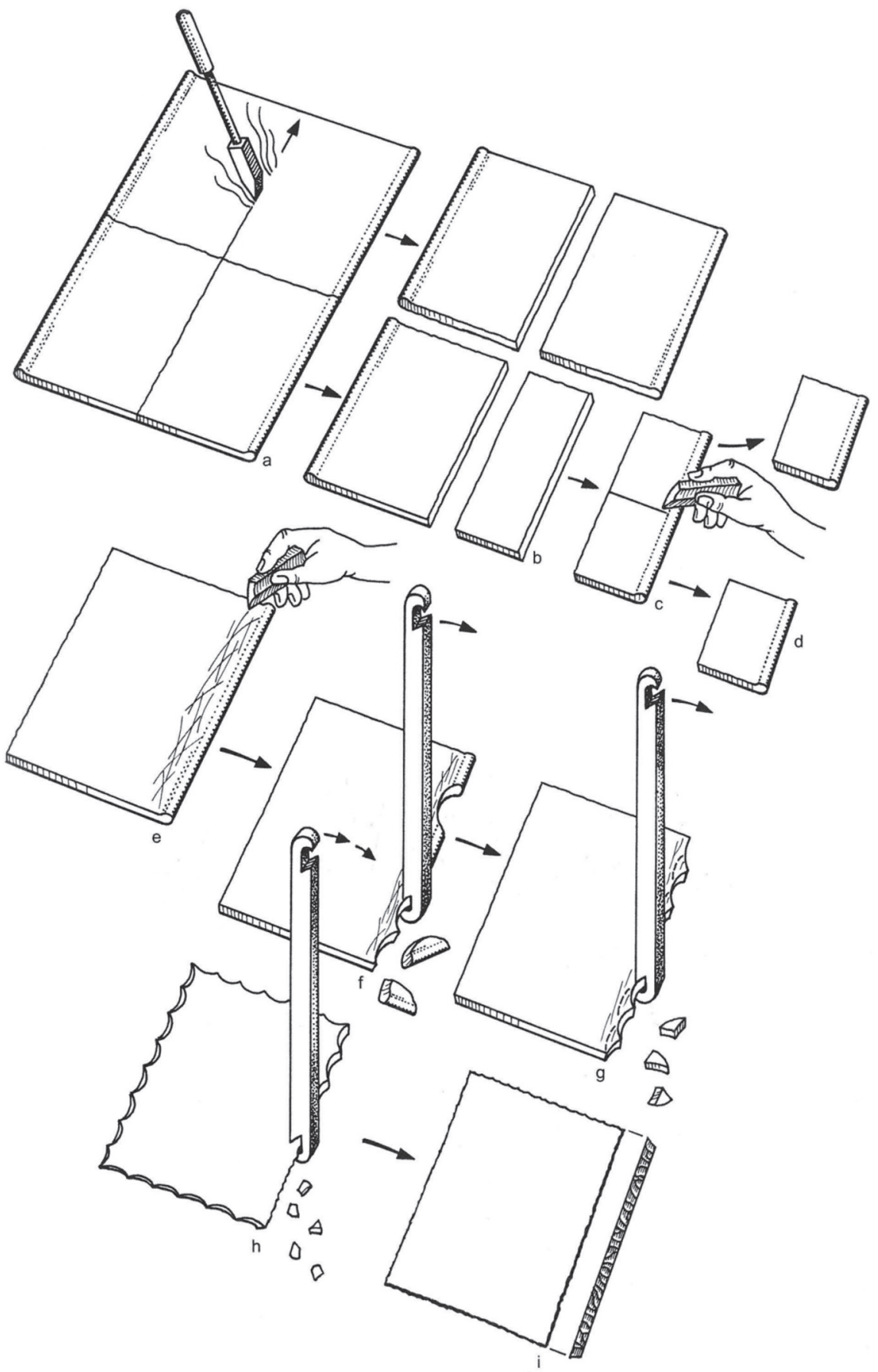

Obr. 9. Rekonstrukce procesu výroby okenních tabulek. Podle Kaufmann 2010, Abb. 54 na s. 135.

Abb. 9. Rekonstruktion des Herstellungsprozesses von Fensterscheiben. Nach Kaufmann 2010, Abb. 54 auf S. 135. 
a v období renesance. Optickým dekorem je zdobena i zkorodovaná poutnická láhev. Tyto láhve původně sloužily poutníkům k přepravě a uchovávání vody nebo oleje z poutních míst a poté jako suvenýr. Pravděpodobně však časem ztratily svoji primární funkci a byly používány i při stolování. Častěji se poutnické láhve objevují v archeologických kontextech až od poloviny 16. století. Jediným dalším opavských exemplářem z období druhé poloviny 15. až počátku 16. století je láhev z kostela sv. Ducha (Sedláčková-Rohanová et al. 2016, 116).

Další výzdobnou inovací je motiv klikatek a vláken promačkávaných rádélkem. Z takto zdobené nádoby se však v jímce zachoval pouze jeden zkorodovaný zlomek výdutě. Unikátním nálezem je nádoba zdobená výrazně vytaženými nálepy ze zkorodovaného skla, která dosud nemá v českém Slezsku obdoby. Za zmínku stojí i torzo čočkovité láhve ze zkorodovaného skla, jež zřejmě představuje jeden $\mathrm{z}$ nejstarších nálezů tohoto typu. Tento specifický tvar mohl být používán naprríklad na tekuté koření při stolování nebo k vyhlazování textilu (Jordánková-Sedláčková 2005, 132).

V českém Slezsku není souborů skla z období konce 15. a počátku 16. století mnoho. Jako př́íklad lze uvést nálezy z hradu Sovince, Cvilína u Krnova (Sedláčková 2004) a z Opavy, z vnitrobloku Mnišská-Mezi Trhy, Pekařská-Kolářská (Břečková 2017, 270-271) a z Kolářské ulice (Sedláčková 2004a, 237-240). Přesto zde však v první polovině 16. století nepozorujeme tak výrazný úbytek skleněných předmětů jako v Brně.

Sklo renesanční představuje číška s modrými vlákny v okraji, která se složením skla podobá výrobkům regionálních skláren. Tyto číšky byly v první polovině 16 . století oblíbené v Německu, odkud se dostávaly i do českých zemí. Vzhledem k jejich nenáročné výrobě však nelze vyloučit ani produkci v dalších regionech. Hedvika Sedláčková jejich výskyt na Moravě spojuje s působením novokřtěncủ (Sedláčková ed. 2019a, 226-227). Mezi čistě renesanční tvary pak patří tři poháry s nálevkovitou kupou hladkou nebo zdobenou optickým dekorem, láhve s kulovitým nebo hruškovitým tělem z nazelenalého skla, mucholapka s výlevkou a několik číší na duté zvonovité patce.

\section{Sklo v renesančním stylu}

Kromě již zmíněných nádob z odpadní jímky 500 bylo sklo renesančního tvarosloví vyzvednuto také z jímky 515 a z vrstvy 175 v jímce 508. Mezi nejrozšířenější tvary nápojového skla v období renesance patřily poháry různých forem i dekoru, ale také číše na duté zvonovité patce. Tomu odpovídá i charakter nálezů z Drůbežího trhu. V odpadních jímkách 508 a 515 jsou doloženy poháry s nezdobenou polovejčitou a nálevkovitou kupou a se zvonovitou nebo terčovitou patkou, ale také poháry s tyčinkovitým dříkem a patkou ze svinutého vlákna, které patřily mezi nejjednodušší sklářské výrobky. Jejich nenáročná výroba umožnila masovou produkci a rozšíření mezi široké vrstvy, což dokládají nálezy z řady lokalit v Opavě z kontextů druhé poloviny 16. až počátku 17. století.

Vedle těchto základních forem nápojového skla měli obyvatelé domů na ulici Mezi Trhy přístup také ke kvalitnějšímu sklu, které bylo často zdobené malbou barevnými emaily a zlacením. Mezi takové nádoby patří číše na duté zvonovité patce s motivem jezdce (Turka) na koni, konvalinkami a letopočtem. Dekor konvalinek, obvykle doplněný figurálním motivem, byl v českém Slezsku velmi oblíbeným výzdobným vzorem. Z Opavy známe další číše zdobené malbou např́iklad z vnitrobloku mezi ulicemi Pekařská a Kolářská, z Horního náměstí (Pavelčík-Štěrbová 1997, 163), Dolního náměstí 18 (Teryngerová 1997) a Kolářské ulice (Sedláčková-Rohanová et al. 2016, tab. 18). K luxusnějšímu zboží patřil i pohár s nálevkovitou kupou zdobený opět konvalinkami, mřížkou s květinami a zlacením. Tyto číše a poháry bohatě zdobené emaily a zlatem měly kromě primární funkce při stolování i funkci reprezentativní. Inspiraci českých sklářů benátskými vzory dokládají poháry s motivem lvích maskaronů z jímky 515 . Poháry s tímto dekorem byly oblíbené na rozsáhlém území Evropy a po vzoru benátských skláren je ve druhé polovině 16. století vyráběly sklářské hutě v různých oblastech, např́klad v Reichenau a Hall (Karel 2017, 97; Tarcsay 2007, Abb. 118 na s. 233). Do svého sortimentu je zařadili také čeští 
skláři (Žegklitz 2007, obr. 39:7 na s. 170). V porovnání s brněnskými soubory se však v Opavě poháry s reliéfně zdobenými nody objevují pouze sporadicky. Další pohár se lvími maskarony je na severní Moravě doložen na zámku v Janovicích (Karel 2017, tab. 6:1 na s. 104).

Zajímavé zjištění přinesly analýzy složení vybraných skel, které odhalily korelaci mezi obsahem $\mathrm{Na}_{2} \mathrm{O}$ a náročností výzdoby. Vyšší obsah $\mathrm{Na}_{2} \mathrm{O}$ byl zjištěn u poháru (obr. 7:15; tab. 3:A18) a číše zdobené emaily (obr. 7:11; tab. 3:A26), poháru se lvími maskarony (obr. 7:17; tab. 3:A20) a další číše na duté zvonovité patce (tab. 3:A23). Nádoby s náročnější výzdobou, u nichž lze předpokládat $i$ vyšší pořizovací náklady, byly tedy vyrobeny z kvalitnějšího skla. Tuto teorii potvrdily i analýzy vzorků z dalších opavských lokalit (Vad’urová 2021, 245). To ukazuje na skutečnost, že již ve sklářských hutích byly rozlišovány luxusnější nádoby určené k pozdějšímu zdobení a levnější zboží bez dekoru.

Vedle nápojového skla tvoří velkou část renesančních souborů z Drůbežího trhu láhve s hruškovitým nebo kulovitým tělem i láhve čtyřboké, jež vedle funkce stolního skla sloužily ke skladování tekutin. V renesanci dosáhla větší obliby i skla barevná, především tmavě modrá, ale také fialová a skla opakní (červená, světle modrá). Na Drůbežím trhu však kromě několika zlomků modrého skla z jímky 500 nejsou nádoby z barevných skel doloženy. Nápadná je také absence jednoduchých válcovitých číšek, které jsou běžnou součástí renesančních souborů z řady parcel v historickém centru Opavy. Zvláštní funkci měly mucholapky nalezené v jímce 500, jejichž účelem, jak napovídá samotný název, bylo lapání obtížného hmyzu.

\section{Závěr}

Soubor skla získaný z archeologického výzkumu na Drůbežím trhu představuje průřez sklářskou produkcí od 13. do 16. století. V rámci Opavy se jedná o jednu z nejbohatších kolekcí skla obsahující torza a fragmenty zhruba 170-180 nádob, přičemž větší část tvořilo sklo středověké, které bylo získáno téměř ze všech odpadních jímek zachycených na lokalitě. Sklo raně novověké zde již nebylo zastoupeno tak četně, početnější nálezy pocházejí pouze z jímek 500 a 515 . Kromě velkého počtu nádob však tento soubor nijak výrazněji nevybočuje z řady dosud zpracovaného materiálu z archeologických výzkumů historického centra Opavy. Přínosem souboru z Drůbežího trhu je však také kvalitní zpracování terénní dokumentace výzkumu, jež výrazně zvyšuje jeho vypovídací možnosti.

Nálezy skel dokládají, že již ve 13. století měli obyvatelé domů na parcelách, k nimž náležely odpadní jímky, přístup k luxusnímu sklu dováženému z Benátek, ale také ke sklu německému (mohli ho s sebou přivézt němečtí kolonisté). Již záhy, ve 14. století, však v jejich domácnostech naprosto převládly skleněné nádoby regionální provenience $s$ dominantním zastoupením číší českého typu, zatímco importované zboží tvořilo pouze minoritní složku stolního skla. Tato situace přetrvávala i v následujícím století. Podobné vývojové tendence pozorujeme v celém českém Slezsku i na severní Moravě. Jak v keramickém, tak i skleněném materiálu z odpadních jímek náležejících právovárečným domům na ulici Mezi Trhy byly doloženy tvary, které lze spojit s konzumací piva a mohly být uživány i při hostinské činnosti provozované v těchto šenkovních domech (Zezula 2015, 102-103, 106-108). O dalších řemeslech, jež obyvatelé těchto domů vykonávali, nás informuje nález odpadu po opracování okenního skla, který dokládá působení sklenáře na lokalitě v první polovině 15 . století.

Teprve v závěru 15. století a v 16. století se repertoár stolního skla rozšiřuje a objevuje se zde řada „nových“ tvarů, jako jsou čočkovité láhve, mucholapky, džbánky či konvičky a stolní láhve s optickým dekorem. Řada inovací se projevila také ve výzdobě. Sklo renesančního tvarosloví z Drůbežího trhu koresponduje s nálezy z dalších parcel v blízkosti obou náměstí, kde se nacházely domy majetnějších Opavanů. 
Studie vznikla $\mathrm{v}$ rámci výzkumného cíle Archeologie financovaného z institucionální podpory Ministerstva kultury ČR na dlouhodobý koncepční rozvoj výzkumné organizace (DKRVO).

\section{Prameny a literatura}

BAKALA, J., 1974: Počátky města Opavy, ČSM B 23, 3-24.

BAUMgartner, E.-KRUEGER, I., 1988: Phoenix aus Sand und Asche. Glas des Mittelalters. Bonn - Basel.

BISZKONT, J., 2005: Późnośredniowieczne szklarstwo na Śląsku. Wratislavia Antiqua 7. Wrocław.

BŘEČKOVÁ, K., 2017: Středověké sklo z Opavy II. Nálezy skla z archeologických výzkumů na ulici Masařská 6, Pekařská - Kolářská a Mnišská - Mezi Trhy, PA CVIII, 257-289.

BŘEČKOVÁ, K. a kol., 2018: Břečková, K.-Marethová, B.-Sedláčková, H.-Turakiewicz, R.-Zezula, M., Katalog vybraných archeologických nálezů z Opavy a Ratiboře. In: S knížaty u stolu. Kuchyně a kultura stolování na středověkých vévodských dvorech v Opavě a Ratiboři (Korbelářová, I.-Zezula, M., edd.), 209-233. Ostrava - Ratiboř.

CZIHAK, E., 1891: Schlesische Gläser. Breslau.

ČERNÁ, E., 2000: K problematice nejstarších nálezů středověkých skel na území Čech - Zur Problematik der ältesten Funde mittelalterlichen Glases in Böhmen. In: Historické sklo 2. Sborník pro dějiny skla, 45-61. Čelákovice.

ČERNÁ, E.-HULÍNSKÝ, V.-GEDEON, O., 2001: Výpověd' mikroanalýz vzorků skel z raného stř̌edověku, AR LIII, 59-89.

DRAHOTOVÁ, O., a kol. 2005: Historie sklářské výroby v českých zemích. I. díl. Od počátků do konce 19. století. Praha.

FITZ, R., b. d.: Die Entstehung der ehemaligen schlesischen Landeshauptstadt Troppau. Strojopis ulož. v Zemském archivu Opava, Písemnosti Rudolfa Fitze, inv. č. 10.

FRÝDA, F., 2007: Nálezy renesančního skla z Plzně. In: Historické sklo 4, 33-66. Čelákovice.

JORDÁNKOVÁ, H.-SEDLÁČKOVÁ, H., 2005: Skleněné střepy a keramické stř́ípy z domácnosti Matouše Židlochovického, BMD 18, 119-143.

KAREL, J., 2017: Kolekce fragmentů renesančního skla ze zámku Janovice u Rýmařova, Střední Morava 23, č. 44, 91-104.

KIECOŇ, M.-ZEZULA, M., 2007: Opava. Drůbeží Trh. Číslo akce NPÚ Ostrava: 50/05. Zpráva o archeologickém výzkumu.

- 2007a: Opava (k. ú. Opava-Město, okr. Opava). Drůbeží trh, parcela č. 606. Středověk, novověk. Město. Záchranný výzkum, PV 48, 494-496.

KOLÁŘ, F.-ZEZULA, M., 2014: Das Stadtgrundstück im Opava des 13. und 14. Jahrhunderts aus archäologischer Sicht. In: Tradition - Umgestaltung - Innovation, Transformationsprozesse im hohen Mittelalter, Praehistorica, Supplementum 1 (Gringmuth-Dallmer, E.-Klápště, J., edd.), 550-553. Praha.

LOSOS, L., 2006: Vitráže. Praha.

MECKING, O., 2013: Medieval Lead Glass in Central Europe, Archaeometry 55, 640-662.

NOWOSIELSKA, K., 2004: Średniowieczne i nowozytne wyroby szklane z badań na Starym Mieście we Wroclawiu. In: Wratislavia Antiqua 6, 59-88. Wrocław.

PAVELKOVÁ, T., 2008: Odpadní jímka z Opavy, parc. č. 606, jímka č. 510. Bakalářská práce, Filozoficko-přírodovědecká fakulta, Slezská univerzita v Opavě. Vedoucí práce Vladimír Goš.

PAVELČÍK, J.-ŠTĚRBOVÁ, J., 1997: Macákové z Ottenburku (historie jednoho opavského domu ve světle archivních pramenů a archeologického výzkumu). In: Sborník prací Filozofické fakulty Ostravské univerzity. Historie, č. 5, 145-172. Ostrava.

RYBNÍČEK, M., 2007: Vnitroblok. Drůbeží trh (50/05) - Opava. Závěrečná zpráva Dendrochronologické laboratoře Ústavu nauky o dřevě Mendelovy zemědělské a lesnické univerzity, ulož. v archivu Odboru archeologie NPÚ, ÚOP v Ostravě. 
SEDLÁČKOVÁ, H., 2004: Archeologické nálezy skla z hradu Cvilín u Krnova, okr. Bruntál - Archäologische Glasfunde auf der Burg Cvilín (Schellenburg) bei Krnov (Jägerndorf), Bezirk Bruntál (Freudental), VVM LVI, 367-379.

- 2004a: Středověké sklo z Opavy - Mittelalterliches Glas aus Opava/Troppau, PA XCV, 223-264.

- 2006: Ninth- to Mid- of 16th Century Glass Finds in Moravia, Journal of Glass Studies 48, 191-224. Corning - New York.

- 2011: Okenní a duté sklo z kostela sv. Martina. In: Kostel sv. Martina v Bohušově (Kozák, P.-Prix, D.-Zezula, M., edd.), 285-306. Bohušov.

- 2011a: Středověké sklo na severní Moravě a přiléhající části Slezska. In: Majer, D.-Antonín, R., Král, který létal. Moravsko-slezské pomezí v kontextu středoevropského prostoru doby Jana Lucemburského, 767-791. Ostrava.

SEDLÁČKOVÁ, H. a kol., 2014: Sedláčková, H.-Rohanová, D.-Lesák, B.-Šimočičová-Koóšová, P., Medieval Glass from Bratislava (ca 1200-1450) in the Context of Contemporaneous Glass Production and Trade Contacts, PA CV, 215-264.

SEDLÁČKOVÁ, H.-ROHANOVÁ, D. et al., 2016: Renaissance and baroque glass from the Central Danube region. Brno.

SEDLÁČKOVÁ, H., ed., 2019: Glass in Brno and Moravia ca. 1200-1550. Assessment of finds. Vol. I. Brno.

SEDLÁČKOVÁ, H., ed., 2019a: Glass in Brno and Moravia ca. 1200-1550. Catalogue of Glass. Vol. II. Brno.

SKALICKÁ, P., 2012: Benátské sklo. In: Předměty vyprávějí... Hmotná kultura středověké a raně novověké Opavy ve světle nálezů z archeologických výzkumů v prostoru bývalé Radniční ulice a v areálu opavského pivovaru, 66-67. Ostrava.

STAMENKOVIĆ, S., 2015: Srednjovekovno staklo manastira Studenice - Medieval glass from the Studenica monastery. In: The Monastery of Studenica, Archaeological Discoveries, 361-377.

STEPHAN, H. G.-WEDEPOHL, H., 1997: Mittelalterliches Glas aus dem Reichskloster und der Stadtwüstung Corvey. Mit einem Nachtrag zu den Analysenergebnissen von Gläsern aus dem Kloster Brunshausen, Germania 75, 673-715.

STIAFFINI, D., 1999: Il vetro nel Medioevo. Tecniche, strutture, manufatti. Rome.

TARCSAY, K., 2007: Das Produktionsspektrum des 16. und 17. Jhs. im Österreichischen Teil des Böhmerwaldes. In: Historické sklo 4, 101-106. Čelákovice.

TERYNGEROVÁ, H., 1997: Kolekce renesančního skla z opavských archeologických nálezů. In: Sborník Památkového ústavu v Ostravě, 69-72. Ostrava.

VAĎUROVÁ, K., 2021: Sklo z archeologických výzkumů a vývoj sklářství ve Slezsku ve středověku a raném novověku. Disertační práce. 1. díl - Text. ÚAM FF MU, Brno. Vedoucí práce Irena Loskotová.

VANDINI, M. a kol., 2018: Vandini, M.-Chinni, T.-Fiorentino, S.-Galusková, D.-Kaňková, H., Glass production in the Middle Ages from Italy to Central Europe: the contribution of archaeometry to the history of technology, Chemical papers 72, 2159-2169.

ZEZULA, M., 2015: Odraz konzumace piva v archeologických nálezech z Opavy. In: Opavský pivovar (Švábenický, F., ed.), 100-115. Opava.

ŽEGKLITZ, J., 2007: Renaissance glassworks in Broumy - Renesanční sklářská hut’ v Broumech. In: Studies in Post-medieval Archaeology 2 (Žegklitz, J., ed.), 145-180. Praha.

\section{Zusammenfassung}

Glas aus Abwassergruben vom Drůbeží trh (Geflügelmarkt) in Opava (Troppau) und Überbleibsel einer Glaswerkstatt

Bei archäologischen Grabungen im historischen Zentrum Opavas wurden zahlreiche Funde mittelalterlichen und frühneuzeitlichen Glases entdeckt, die einen deutlichen Beitrag zu den Erkenntnissen über den Alltag unserer Vorfahren, über das Niveau der Handwerke und über die Handelskontakte leisten können. Einer der umfangreichsten Fundkomplexe stammt aus einer 
Reihe von am Geflügelmarkt entdeckten Abwassergruben, wo in den Jahren 2005-2007 unter der Leitung des Nationalen Denkmalamtes, Gebietsfacharbeitsstelle Opava eine archäologische Grabung durchgeführt wurde (Abb. 1-2; Kiecoň-Zezula 2007). Die Torsi und Fragmente von einer ca. 170-180 Gefäßen enthaltenden Glaskollektion stellt einen Querschnitt der Glasproduktion für die Zeit ab dem 13. bis ins 16. Jahrhundert dar. Der größte Teil davon bildete mittelalterliches Glas, das fast in allen Abwassergruben entdeckt wurde, während frühneuzeitliches Glas lediglich in den Gruben 500, 508 und 515 vertreten war.

Die ältesten, bereits ins 13. Jahrhundert datierten Funde wurden außer in den Gruben 534 und 570 auch in archäologischen Situationen außerhalb von eingetieften Objekten entdeckt. Das Glassortiment aus diesem Zeitraum besteht vornehmlich aus Waren, die aus höher entwickelten Glasgebieten importiert worden waren, besonders Flaschen mit Innenring aus braunem und farblosem Glas, Trinkbecher mit Aufschmelzungen und ein beidseitig emailleverzierter Trinkbecher. Diese Trinkbecher wurden in den Jahren 1280-1350 in Venedig hergestellt, von wo aus sie als Prestigehandelsartikel nach Europa und Asien exportiert wurden. Fremder Provenienz ist auch ein Gefäß mit massiven Rippen aus braunem Glas. Eine Schüssel mit ähnlichem Dekor und einer Analogie in Sizilien wurde in Brünn gefunden. Diese am Geflügelmarkt gemachten Glasfunde sind ein Beleg für das große Handelspotenzial der Troppauer Bürger. Neben Gefäßen aus qualitativ gutem Glas tauchten dort jedoch auch Fragmente von korrodierten Gefäßen auf, deren Herkunft in den böhmischen oder deutschen Glashütten gesucht werden kann.

Eine umfangreiche Glaskollektion von der Wende des 14. und 15. und dem Verlauf des 15. Jahrhunderts stammt aus den Gruben 504 (Abb. 4), 505 (Abb. 5), 508 (Abb. 6:1-11, 15) und aus dem unteren Teil von Grube 515 (Abb. 7:1-6). Die dominante Form hier war durch mit Aufschmelzungen verzierte Trinkgläser böhmischen Typs vertreten, die ein typisches Produkt böhmischer Glashütten waren und im 14.-15. Jahrhundert im tschechischen Schlesien den häufigsten Hohlglastyp darstellten. Neben den Trinkgläsern böhmischen Typs tauchen sporadisch auch andere Formen auf, beispielsweise Trinkbecher und Flaschen. Importierte Gefäße sind lediglich durch einige Flaschen mit Innenring und einen Trinkbecher aus binärem Bleiglas vertreten, deren Herkunft in deutschen Glashütten gesucht werden kann. Neben Änderungen des Sortiments und des Verhältnisses von Importen und Produkten heimischer Provenienz beobachten wir im 14.-15. Jahrhundert am Geflügelmarkt gegenüber dem vorhergehenden Zeitraum einen deutlichen Anstieg der Anzahl an Gefäßen. Glas wurde für die breiteren Schichten erschwinglich, was auch durch die Verbreitung von Fensterglas belegt wird.

Eine zahlreiche Kollektion an Fensterglas wurde aus Grube 505 gehoben, die in der ersten Hälfte des 15. Jahrhunderts verfüllt wurde (Abb. 5:12, Abb. 8). Außer einigen Scheiben und bemalten Buntglasfenstern stammen aus dieser Grube über 300 Fensterscheibenfragmente aus grünlichem Glas und Teile von Bleirahmen, mit denen die einzelnen Fenstersegmente miteinander verbunden wurden. Die meisten Scheibenbruchstücke haben eine regelmäßige Form, es überwiegen deutlich sehr kleine und schmale Fragmente. Eine Reihe von ihnen wiesen darüberhinaus Herstellungsspuren auf - vorgerissene Linien und Werkzeugspuren. Die einheitliche Form der Bruchstücke deutet darauf hin, dass es sich um keinen üblichen Haushaltsabfall handelt, sondern um Produktionsabfall, der bei der Bearbeitung von Glasscheiben anfällt. Diese Fragmente können demnach als Beleg für die Existenz einer Glaswerkstatt an diesem Standort in der ersten Hälfte des 15. Jahrhunderts angesehen werden. Aufgrund der Zusammensetzung des Glases ist es wahrscheinlich, dass der dortige Glaser Fensterglas in einer der regionalen Glashütten gekauft und es dann weiterverarbeitet hat.

Eine typologisch reiche Kollektion, in der sich spätgotische und renaissancezeitliche Elemente vermischen, wurde aus der im 15.-16. Jahrhundert verfüllten Grube 500 gehoben (Abb. 3). Zum spätgotischen Glas zählen Trinkgläser mit schlankem Fuß, Trinkbecher mit fadenumwickeltem Boden und korrodierte Flaschen mit Rippen. Einen seltenen Fund stellt ein Kännchen oder kleiner Krug und eine Pilgerflasche mit optischem Dekor dar. Renaissanceglas wird repräsentiert durch drei Pokale, Trinkgläser auf einem hohlen glockenförmigem Fuß, Flaschen mit kugel- oder 
birnenförmigem Körper, einen Fliegenfänger und durch einen Trinkbecher mit blauen Fäden im Rand. Diese Trinkbecher waren jedoch in der ersten Hälfte des 16. Jahrhunderts in Deutschland beliebt, von wo aus sie auch in die böhmischen Länder gelangten.

Außer den bereits erwähnten Gefäßen aus Grube 500 wurde Glas mit renaissancezeitlicher Formgebung auch aus Grube 508 (Abb. 6:12-14) und 515 (Abb. 7:7-20) gehoben. Zu den in der Renaissancezeit am meisten verbreiteten Formen zählten verschieden geformte Pokale, Trinkgläser auf einem hohlen glockenförmigem Fuß und Flaschen mit birnen-/kugelförmigem Körper, ggf. vierseitige Flaschen. Dem entspricht auch der Charakter der am Geflügelmarkt gemachten Funde. Neben den die gängigen Typen für Getränke darstellenden unverzierten Trinkgläsern und Pokalen hatten die Bewohner der Häuser in der Straße Mezi Trhy (Zwischen den Märkten) auch zu repräsentativeren Waren Zugang. Zu solchen Gefäßen zählt ein eimailleverziertes Trinkglas mit dem Motiv eines Reiters, Maiglöckchen und der Jahreszahl sowie ein Pokal mit Maiglöckchen und einem mit Blüten gefüllten Gitter. Eine Inspiration von venezianischen Mustern belegen Pokale mit Löwenmaskaronen, die in der zweiten Hälfte des 16. Jahrhunderts in verschiedenen Gebieten Europas hergestellt wurden, unter anderem auch in den böhmischen Ländern. Am Geflügelmarkt wurde, ähnliche wie auch an anderen Fundstellen in Opava (Vad’urová 2021, 245), eine Korrelation zwischem dem Na2O-Gehalt im Glas und dem Aufwand bei der Anfertigung der Verzierung an den einzelnen Gefäßen festgestellt (Tab. 3). Die Gefäße mit einer anspruchsvolleren Verzierung, bei denen höhere Anschaffungskosten vorausgesetzt werden können, wurden aus qualitativ besserem Glas mit höherem Na2O-Gehalt hergestellt. Offenbar wurde schon in den Glashütten zwischen zur späteren Verzierung bestimmten luxuriöseren Gefäßen und zwischen billigerer Ware ohne Dekor unterschieden.

Große Beliebtheit erlangte in der Renaissancezeit farbiges Glas, das bis auf wenige Bruchstücke dunkelblauen Glases am Geflügelmarkt jedoch nicht belegt ist. Auffällig ist auch das Fehlen einfacher zylinderförmiger Trinkbecher, die sonst gängiger Bestandteil der renaissancezeitlichen Fundkomplexe aus Opava sind. Allgemein korrenspondiert das renaissancezeitliche Glas vom Geflügelmarkt jedoch mit den Funden von anderen Parzellen in der Nähe der beiden Märkte, wo sich die Häuser von vermögenderen Bürgern befanden (vgl. Pavelčík-Štěrbová 1997; Teryngerová 1997).

Die vorliegende Studie entstand im Rahmen des durch institutionelle Förderung vom Ministerium für Kultur der Tschechischen Republik finanzierten langfristigen Entwicklungskonzepts der Forschungsorganisation (DKRVO).

Mgr. Kateřina Vad'urová, Ústav archeologie a muzeologie Filozofické fakulty Masarykovy univerzity, Arna Nováka 1, 60200 Brno, Česká republika, katkabreckova7@gmail.com 
